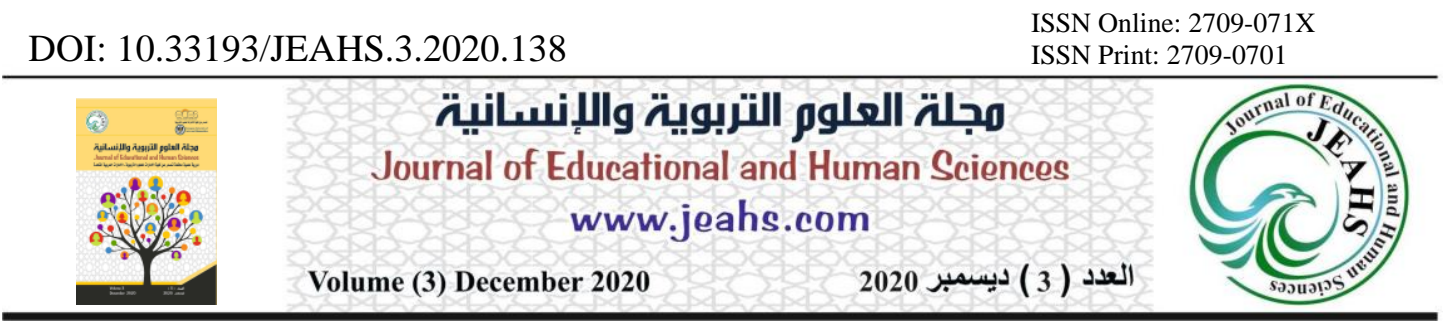

\title{
قلق المظهر وعلاقتهّه بالإخفاقات المعرفية لدى طلبة جامعة سومر لالامر
}

\author{
م.د. اسراء عبدالحسين علي \\ كلية التربية الاساسية - جامعة سومير علئ \\ العراق \\ البريد الاكتروني: yassimiq@yahoo.com
}

الملخص

هدف الدر اسة التعرف على قلق المظهر ، وعلاقتها بالإخفاقات المعرفية لدى طلبة الجامعة، إذ تكون مجتمع

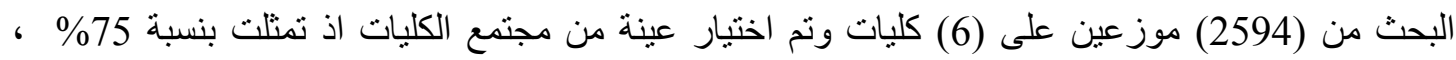
وتكونت عينة الدر اسة من (500) طلبة، وطالبة بو اقع (228) ذكور (272) إناث تم اختيار هم بطريقة عنقودية، وتم استخدام أداتين البحث هما: مقياس قلق المظهر، ومقياس الاخفاقات المعرفية. وتوصلت الدراسة إلى وجود فروق ذات دلالة إحصائية في قلق المظهر لدى طلبة الجامعة، تبعا لـتغير الجنس (ذكور، إناث) ، ولصالح الإناث، وتوصلت الدر اسة الى أن طلبة الجامعة لديهم الاخفاقات المعرفية، وهناك فرق ذات دلالة إحصائية في الاخفاقات المعرفية تبعا لمتغير الجنس إذ كانت ذات دلالة معنويه لصالح الإناث ، وأظهرت النتائج وجود علاقة

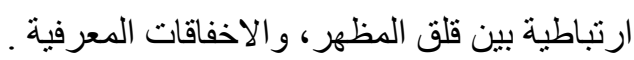

الكلمات المفتاحية: المظهر، الإخفاقات المعرفية، جامعة سومر. 


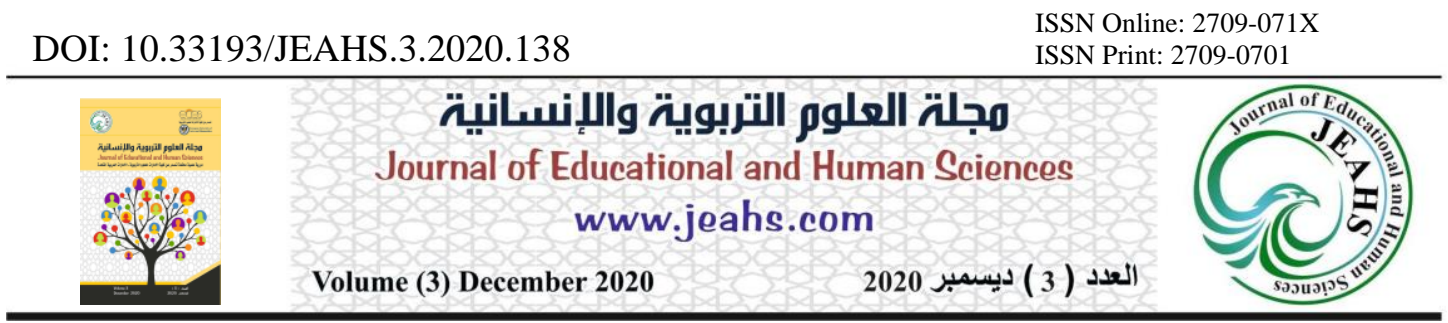

\title{
The Apparent Anxiety and Its Relationship to Cognitive lack of failures among students at University of Sumer
}

\author{
Dr. Israa Abdul-Hussein Ali \\ College of Basic Education - University of Sumer \\ Iraq \\ Email: wassimiq@yahoo.com
}

\begin{abstract}
The study targets to indicate the concern of appearance and its relationship to cognitive failures among university students, where the research community consisted of (2594) distributed among (6) colleges. Male (272) females were selected by the stratified method, and two research tools were used: the Appearance Anxiety Scale and the Cognitive Failure Scale. The study found that there are statistically significant differences in the apparent anxiety of university students according to the gender variable (males, females), and in favor of females. Moral in favor of females, and the results showed a correlation between appearance anxiety and cognitive lack of success, and in light of the study results, a number of recommendations were recommendable .
\end{abstract}

Keywords: appearance, cognitive failures, Sumer University. 


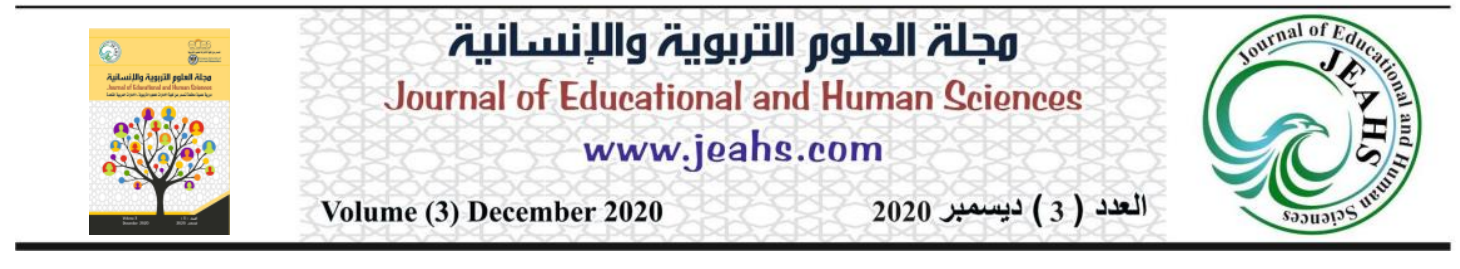

الفصل الاول

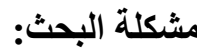

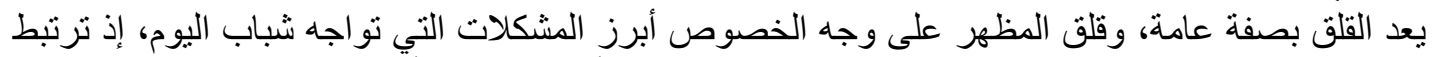

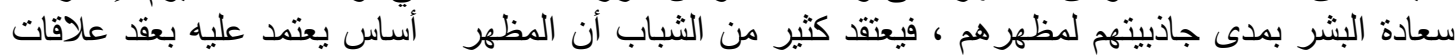

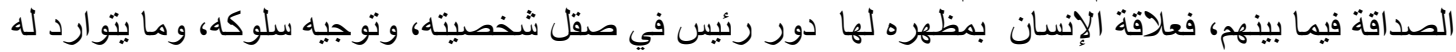

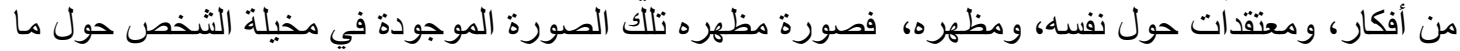

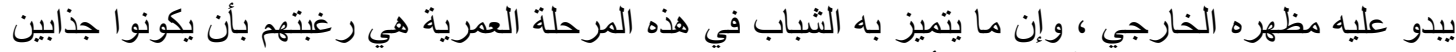

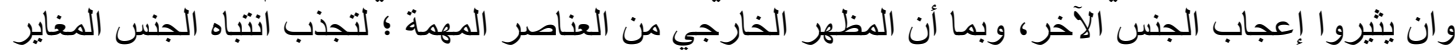

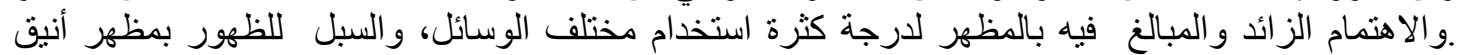

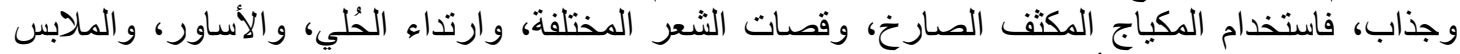

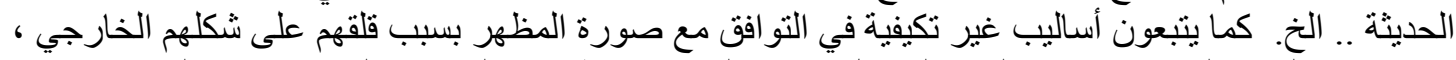

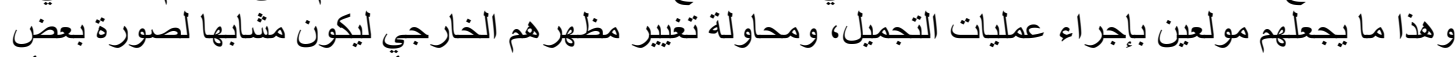

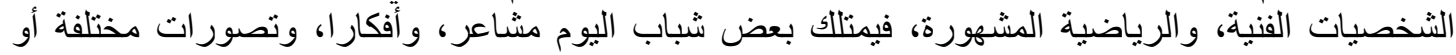

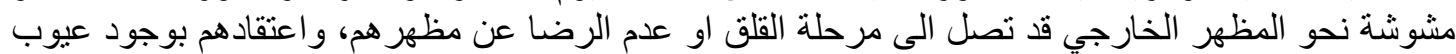

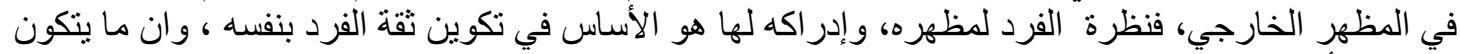

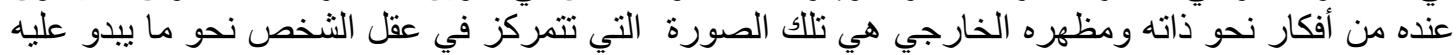

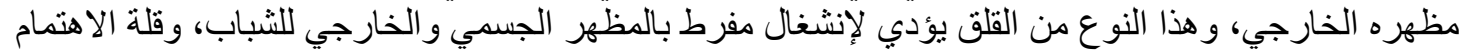

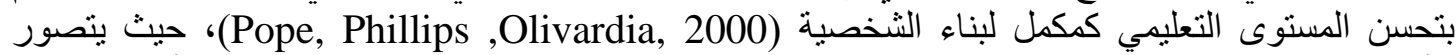

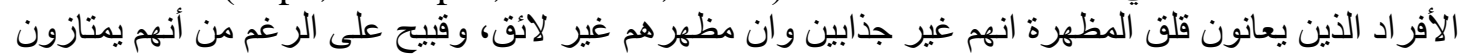

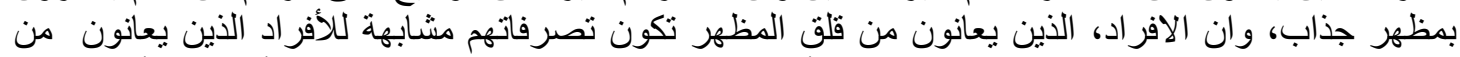

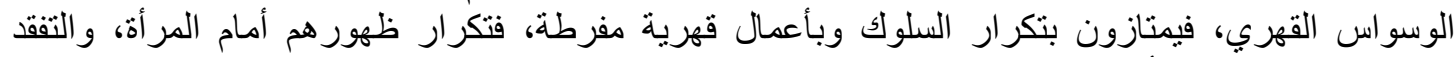

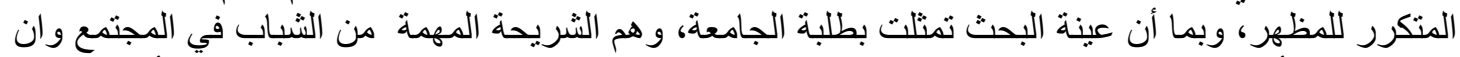

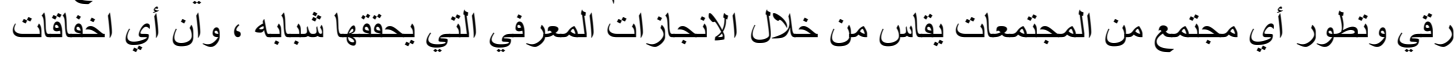

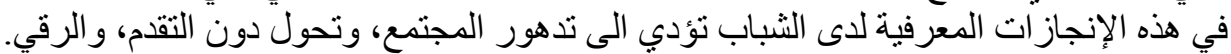

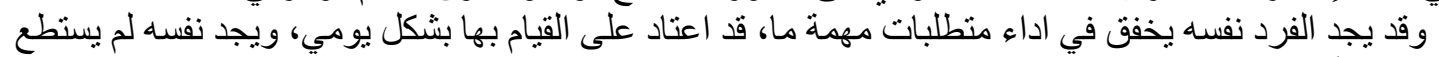

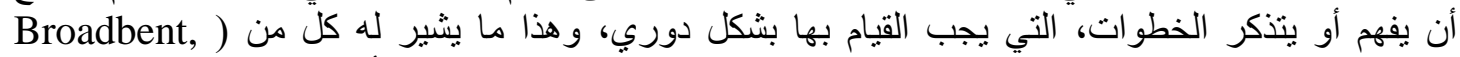
Cooper, FitzGerald \&Parkes

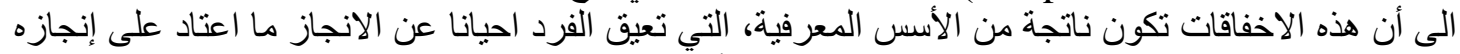

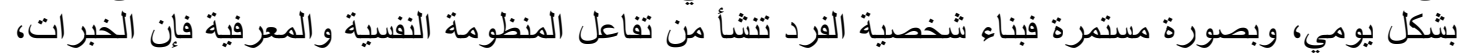

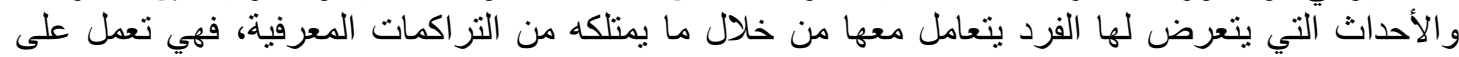

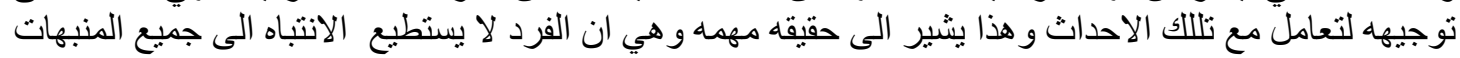

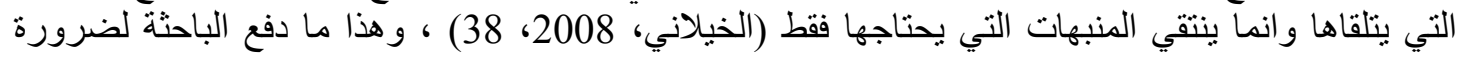

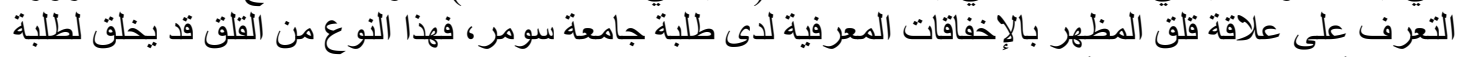

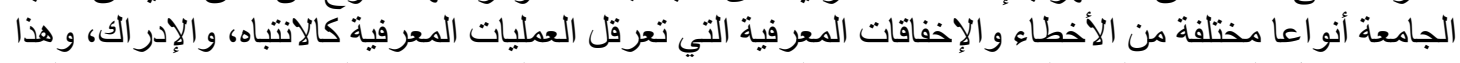

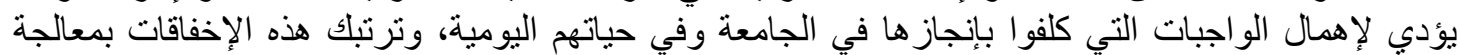

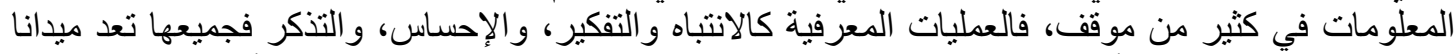

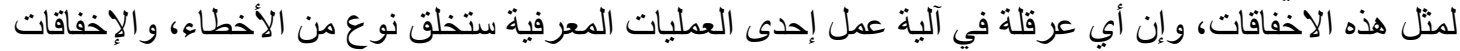

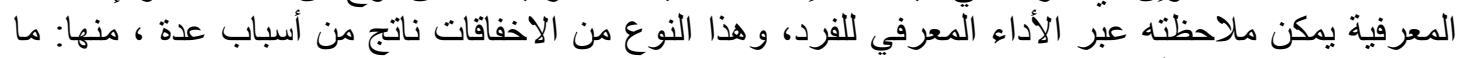

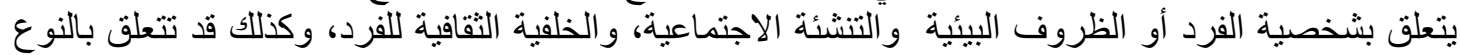

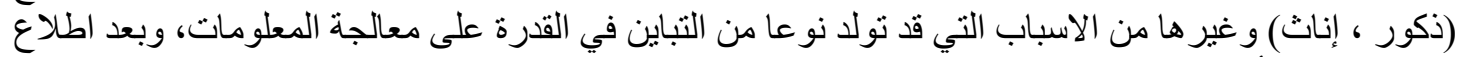

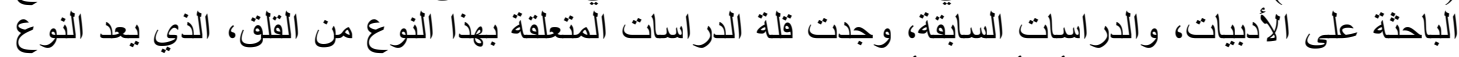

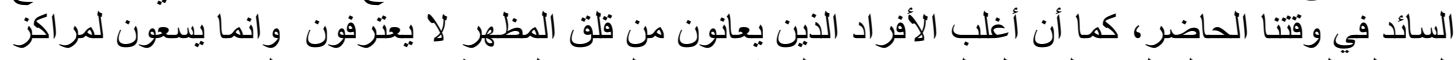

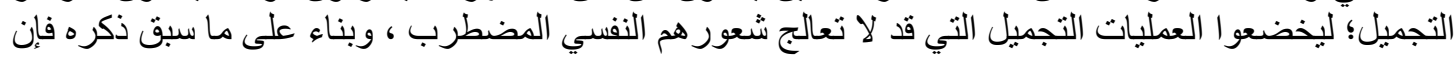




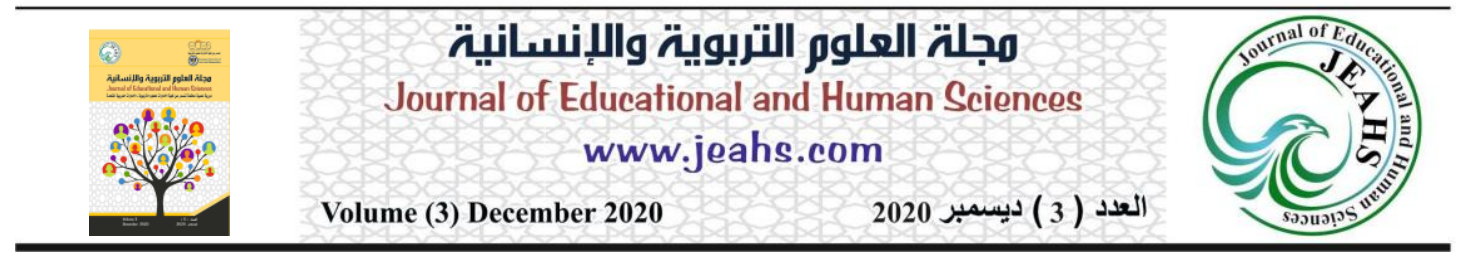

طلبة الجامعة هم الثريحة المهمة من الثباب في المجتمع لذا نثير السؤال الاتي- ما هي نسبة انتشار قلق المظهر

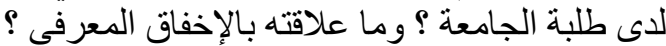

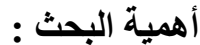

تكتسب هذه الدراسة أهميتها من أهمية الثريحة الثبابية، فطلبة الجامعة هم القوة الاحتياطية التيى تعد نفسها

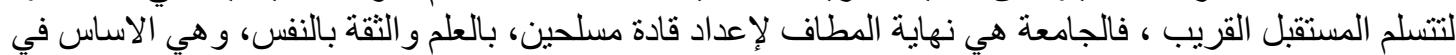

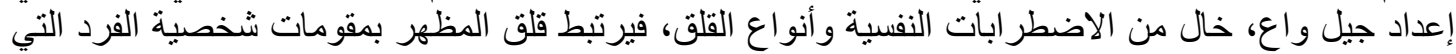

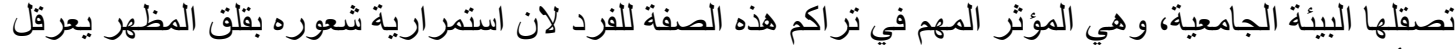

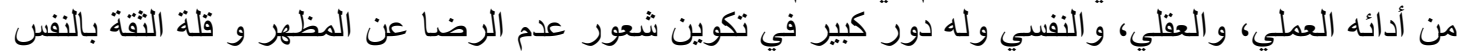

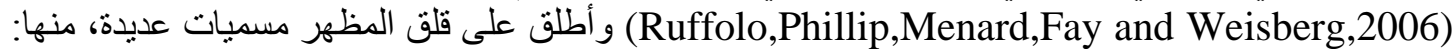

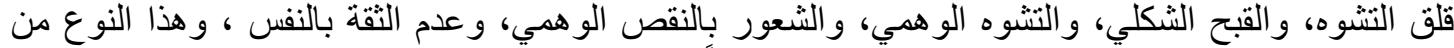

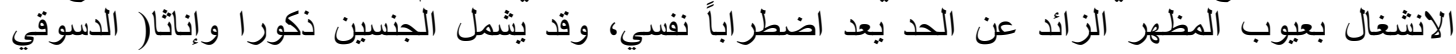

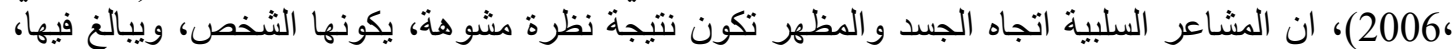
وتولا عنده هو اجس، وقلق يصل به لمرحلة الوسواس اتجاه شكله الخارجي ( Nevid, Rathus and Greene,

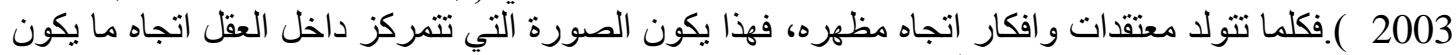

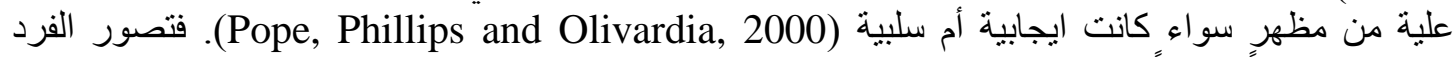
لمظهره له دوراً اساسياً في رسم الصورة الايجابية التي تساعد على بناء الثخصية الناضجة (Stacy,2000).

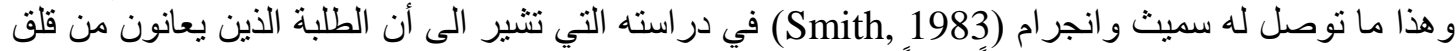

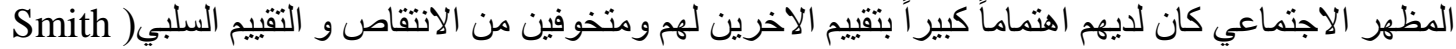

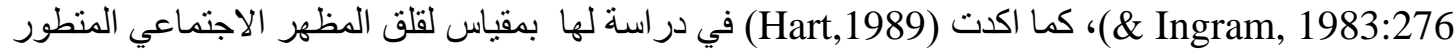

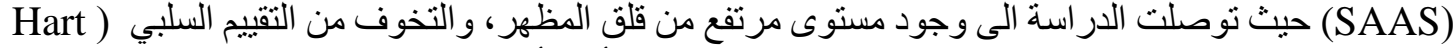
هن 104

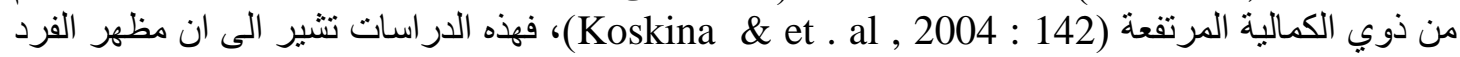

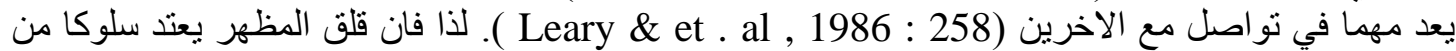

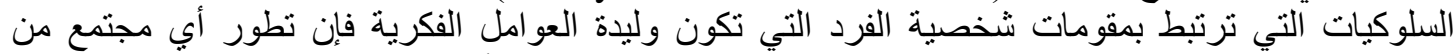

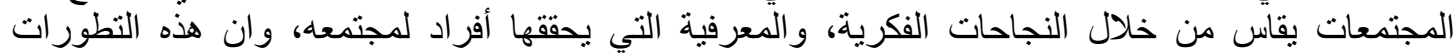

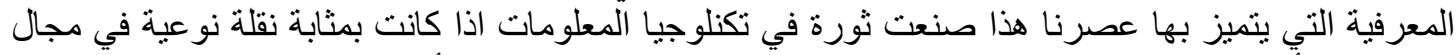

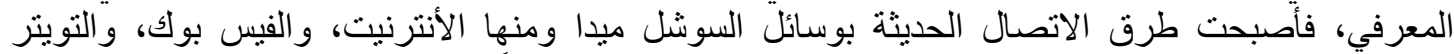

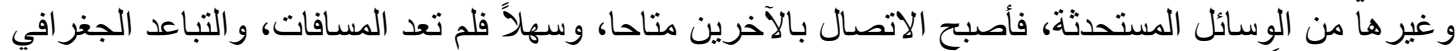

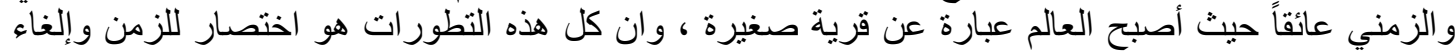

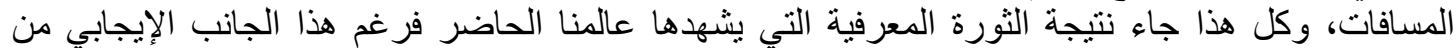

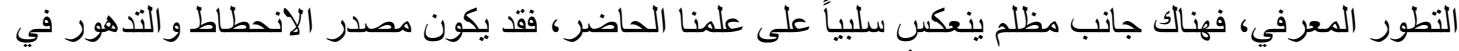

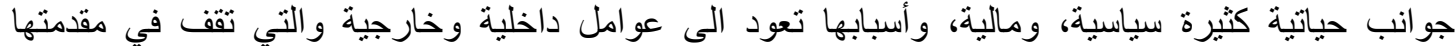

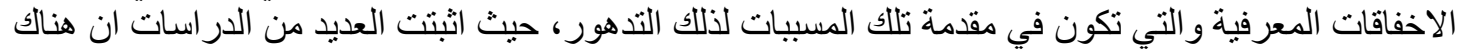

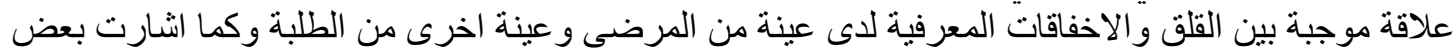

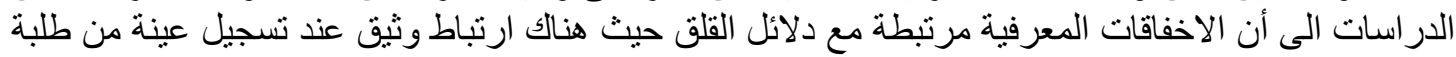
الجامعة على مقياس الاخفاقات المعرفية وبين درجاتهم في مقياس القلق الفات (Merckelbac,1996) .

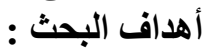

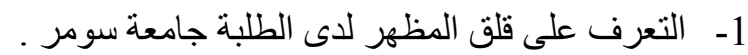

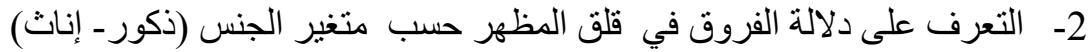

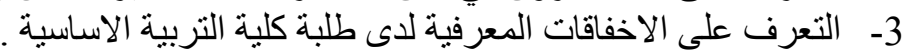

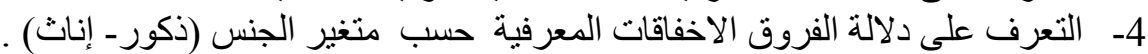

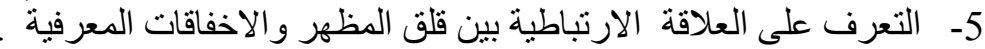


حلود البحث : يتحدد البحث الحالي بطلبة جامعة سومر كلية التربية الاساسية / المرحلة الرابعة / للعام الدر اسي 2019 / 2020 للادر اسة الصباحية الصية

تحديد المصطلحات :

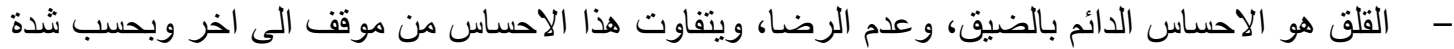
الموقف ويختلف بكونه بمستوى (العالي والمتوسطو المنخفض ) (الكحيمي وآخرون ، 2007)

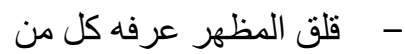

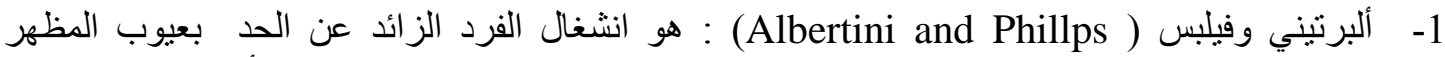

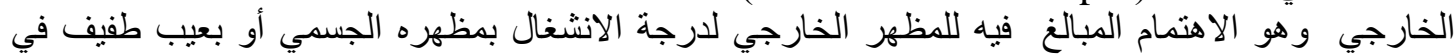

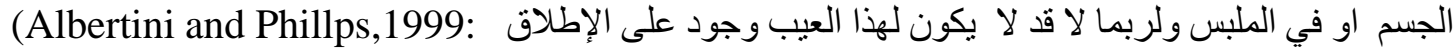

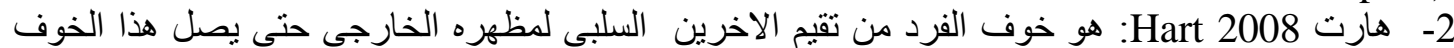

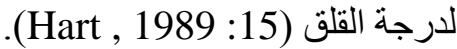
3- التعريف الإجر ائي :هو الارجة التي يحصل عليها المستجيب من خلال استجابته على مقياس قلق المظهر.

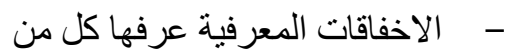

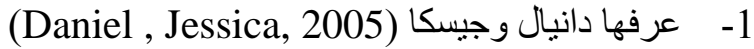
الاخفاقات المعرفية : هي الهمال الاحداث اليومية ويكون مصحوب بتضاؤل الذاكرة واخطاء الادراك

(Daniel,Jessica,2005,104) 2هي عجز الفرد في عملية إدر اكه او تذكرة لتحقيق الحاجات، وإثباعها، وكيفية نوظيفها لأداء مهمة ما و وذذه

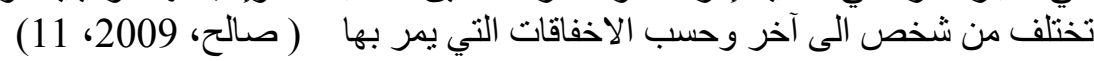

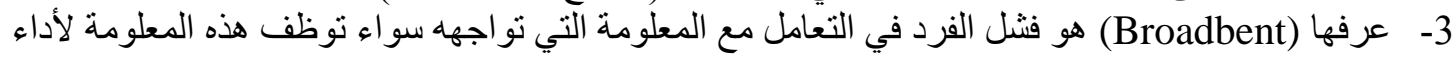

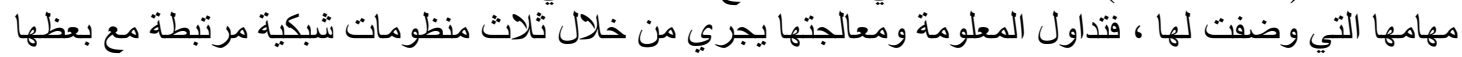
(Broadbent,1982,155) 4- التعريف الاجرائي :هو الدرجة التي يحصل عليها المستجيب من خلال استجابته على مقياس الاخفاقات

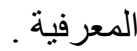

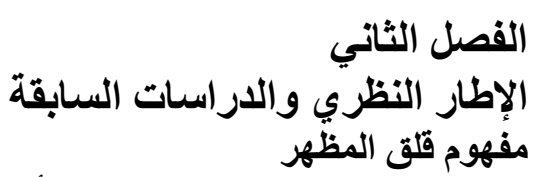

يصنف الباحثون القلق إلى صنفين الأول القلق سمة (Anxiety trait ) و الثاني صنف القلق كحالة ( Anxiety

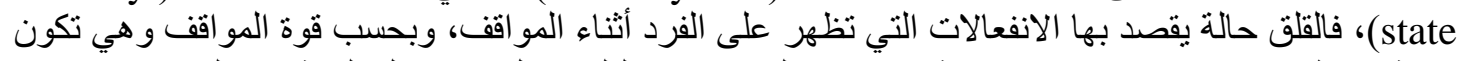

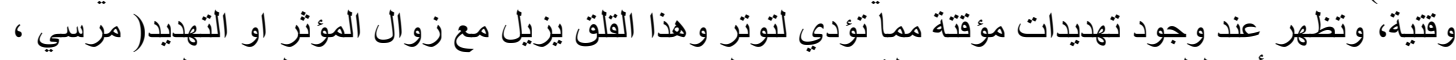

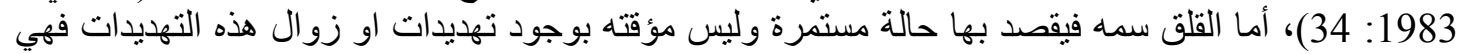

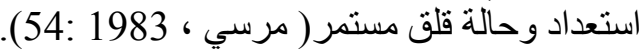
فقلق المظهر هذا النوع الذي يدمج بين هذين الصنفين من القلق كسمة، وحالة فهو ينشأ من خلال السلوكيات

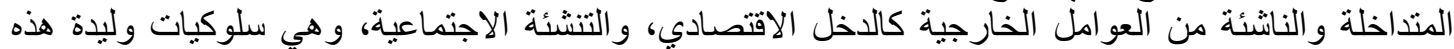

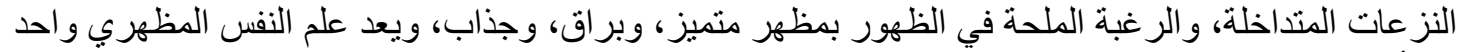

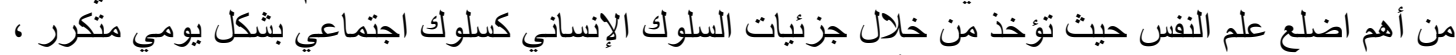

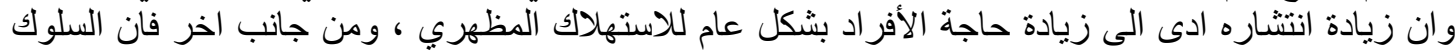

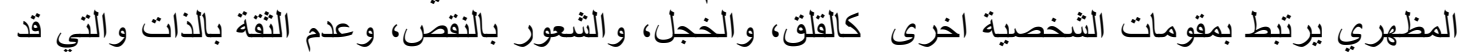

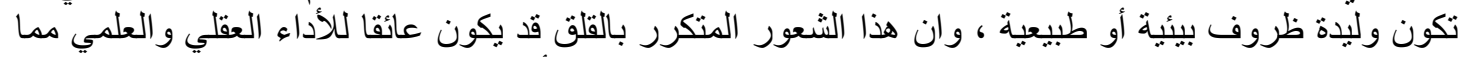

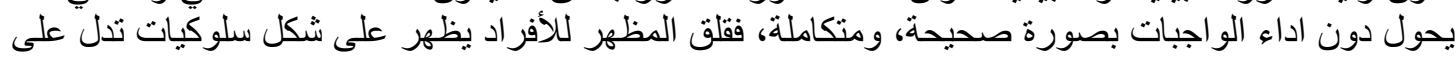




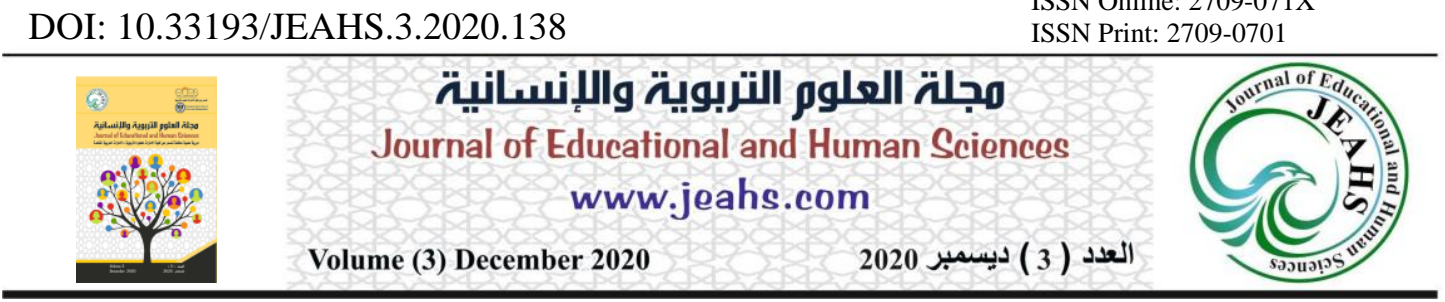

مظاهر اجتماعية ونفسية، وميول الأفراد للظهور بأنثكال مختلفة، وجذابة أمام الاخرين، وان هذا الاهتمام الزائد

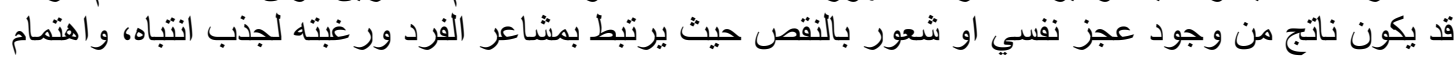

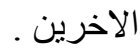

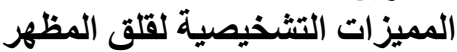

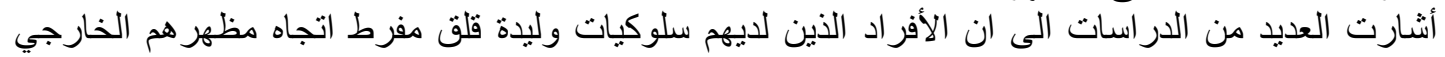

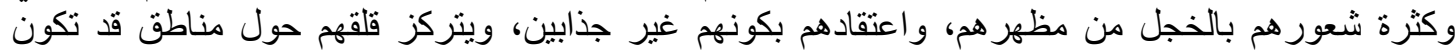

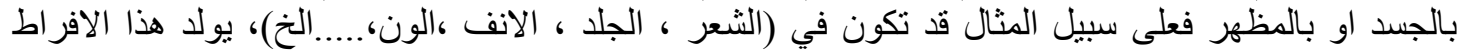

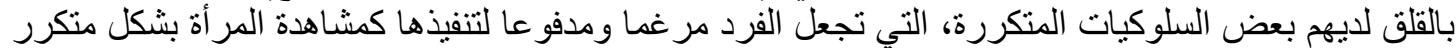

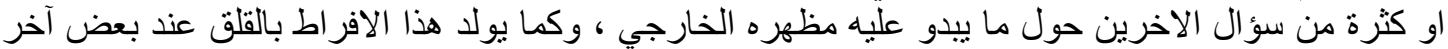

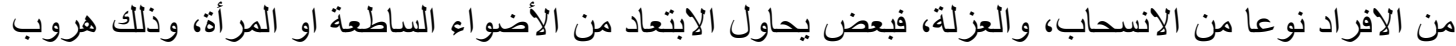

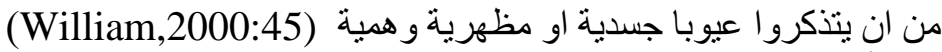

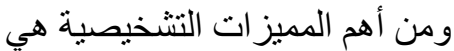
1- التفكير المتكرر، والمستمر وتصور الفرد الفيز بوجود عيوب وهمية في المظهر الخارجي او الثكل.

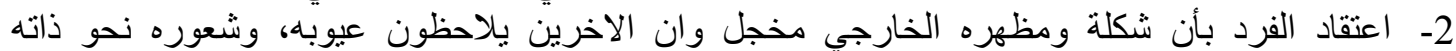
بالانتقاص و الخجل منها.

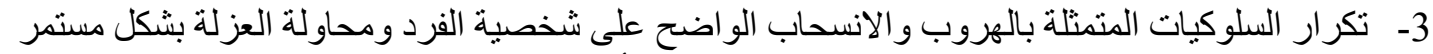
4- التردد وبشكل مستمر على مراكز التجميل، ودور الأزياء بهذف محاولة اخفاء العيوب الوهية همية في 5- يمتلكون صفات الثخصية السواسية المنمتلة في الظهور المتكرر امام المر أة و السؤال المتكرر على ما يبدو عليه مظهر هم الخارجي. (William,2000:45)

النظريات المفسرة لقلق المظهر

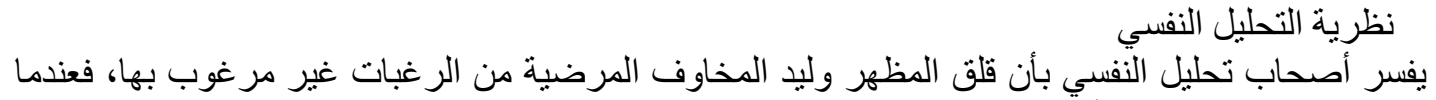

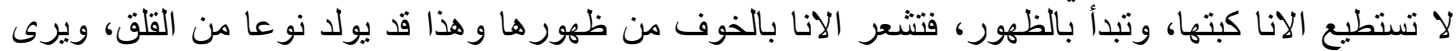

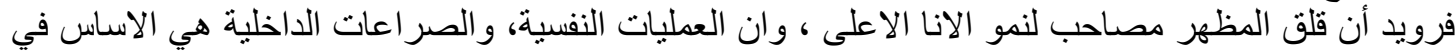

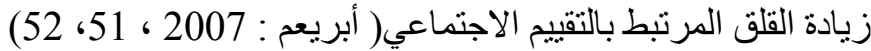

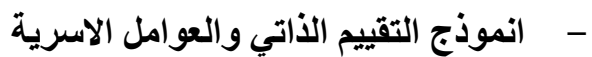

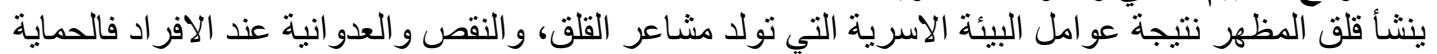

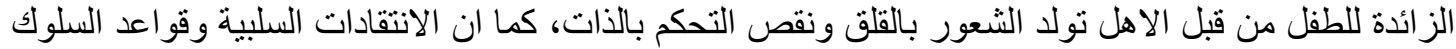
الجامدة تسبب الثعور بالنقص و انتقاد الذات (Baumeiseter,Roy \& Vohs , Kathleen : 2007 , 880)

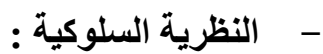

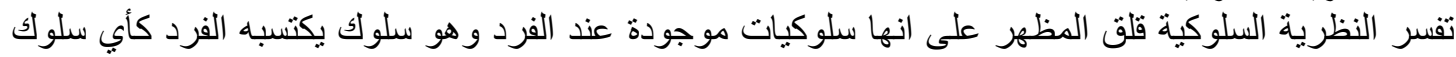

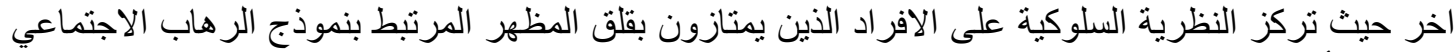

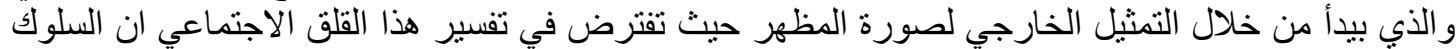

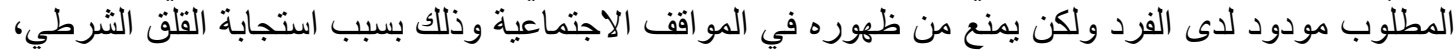

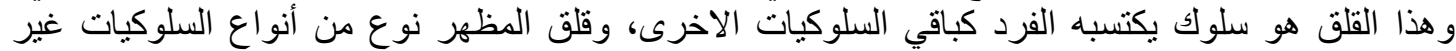

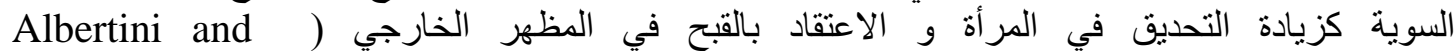

(Phillps, 1999,56

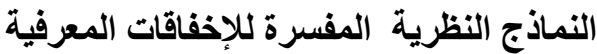
يعد الانتباه للمثير ات من المسلمات الاساسية و التي تكون من خلال القنوات الحسية محدد و انتقائي (Selection) 


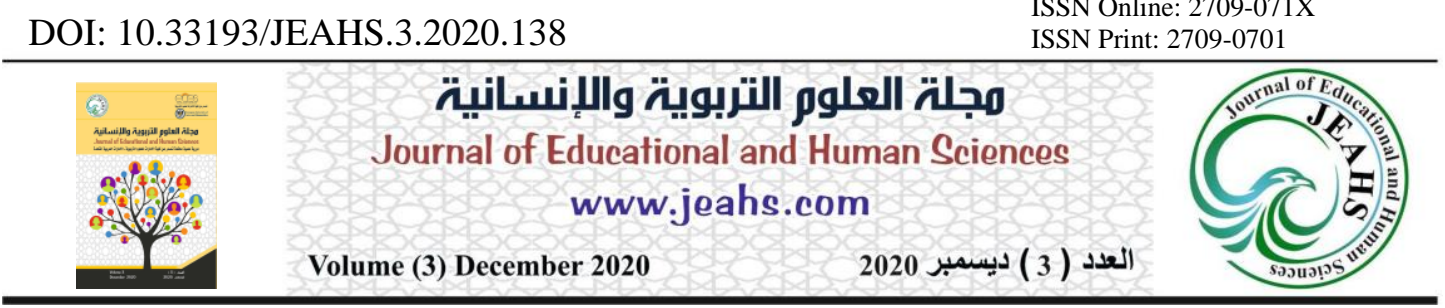

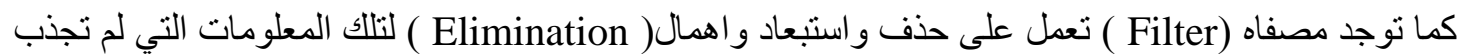

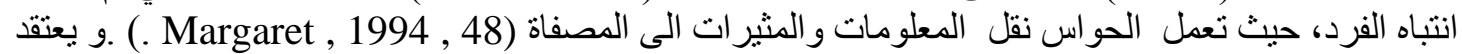

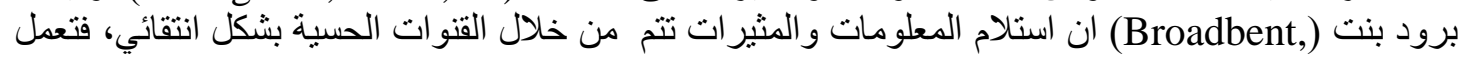

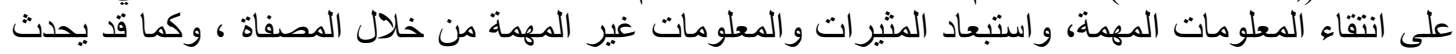

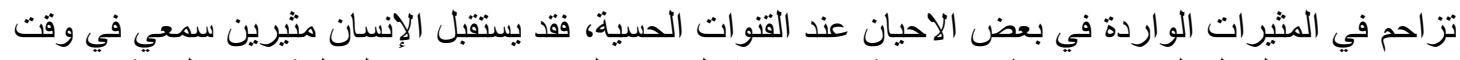

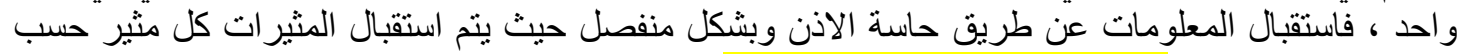

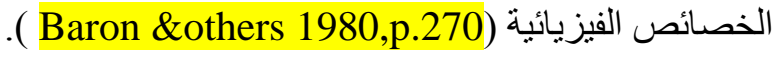

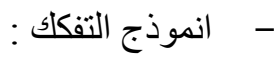

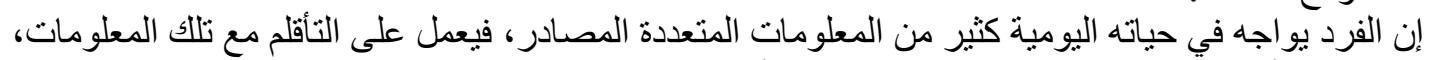

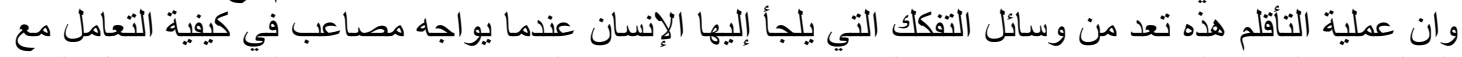

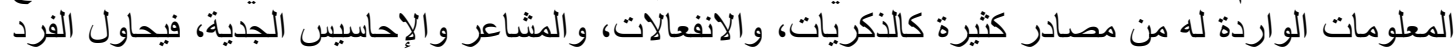

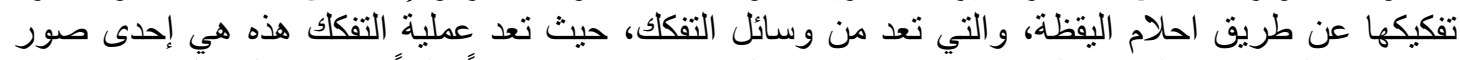

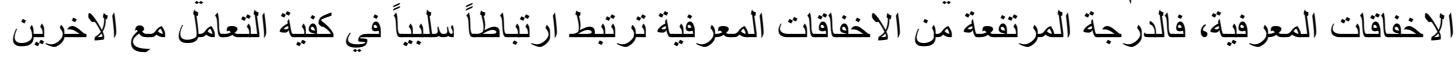

(Carlson \& Putnam, 1993 : 16-27) -

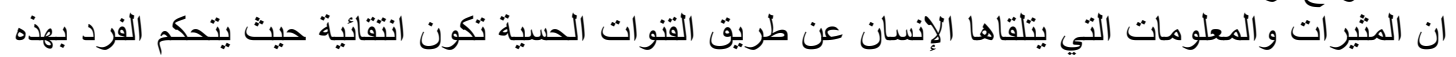

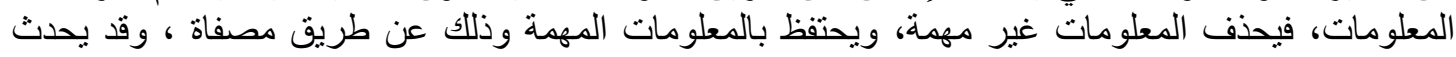

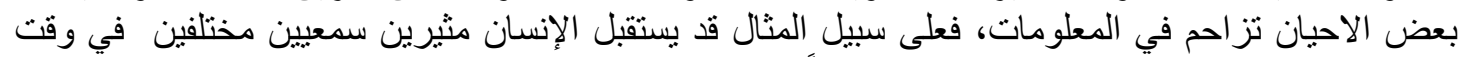

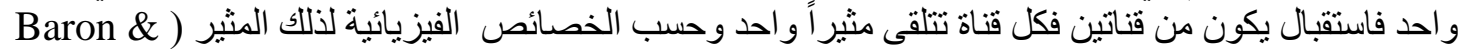
(others $1980: 270$

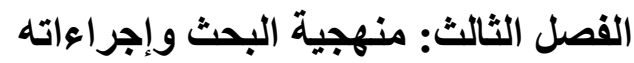

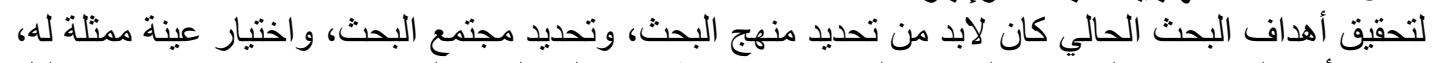

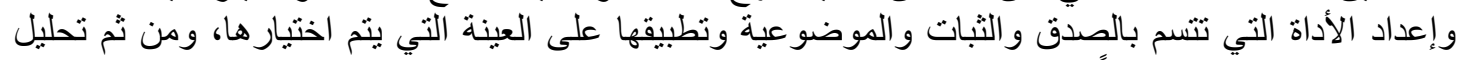

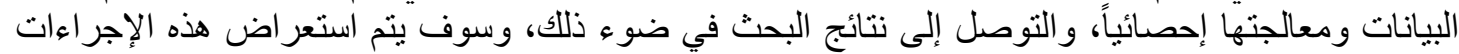

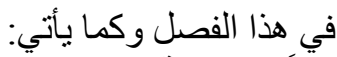

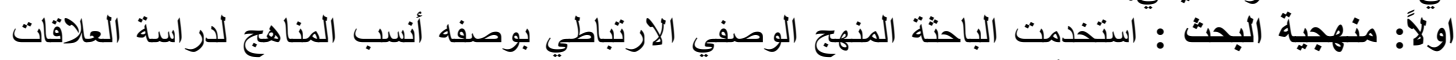

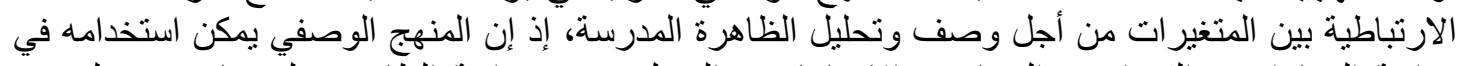

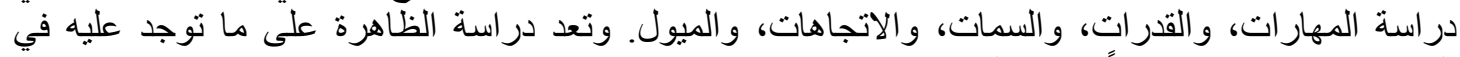

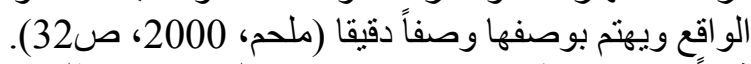

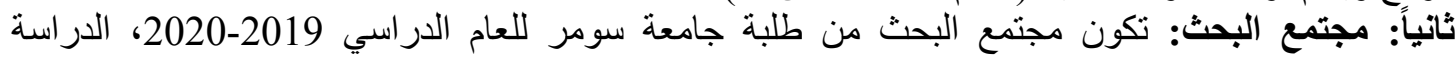

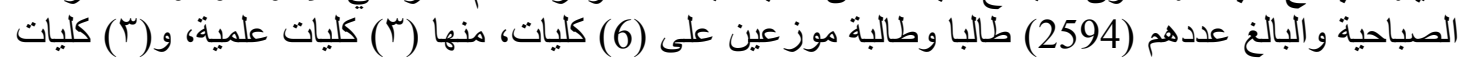
انسانية وكما موضح في الجدول (1). 


\section{مجلة العلوم التربوية والإنسانية}

Journal of Educational and Human Sciences www.jeahs.com

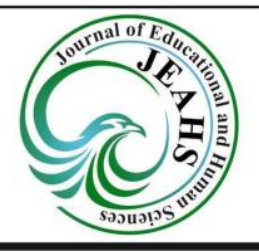

جدول (1) مجتمع البحث موزع بحسب الكلية والجنس والمرحلة الاراسية

\begin{tabular}{|c|c|c|c|c|c|c|c|c|c|}
\hline \multirow{3}{*}{ المجموع } & & & \multicolumn{6}{|c|}{ 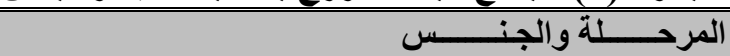 } & \multirow{3}{*}{ الكا } \\
\hline & \multicolumn{2}{|c|}{ المرحلة الرابعة } & \multicolumn{2}{|c|}{ المرحلة الثالثة } & \multicolumn{2}{|c|}{ المرحلة الثانية } & \multicolumn{2}{|c|}{ المرطلة الأولى } & \\
\hline & إناث & ذكور & إناث & ذكور & إناث & ذكور & إناث & ذكور & \\
\hline 920 & 113 & 35 & 167 & 128 & 166 & 111 & 128 & 72 & التربية الاساسية \\
\hline 176 & 15 & 22 & 12 & 12 & 21 & 25 & 24 & 45 & تكنولوجيا المطلومات \\
\hline 823 & 94 & 128 & 80 & 87 & 78 & 104 & 128 & 124 & الإدارة والاقتصاد \\
\hline 339 & 72 & 51 & 51 & 48 & 45 & 36 & 12 & 24 & الزراعـــــة \\
\hline 226 & 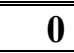 & 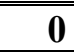 & 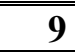 & 33 & 22 & 63 & 47 & 52 & القانــــون \\
\hline 110 & $\mathbf{0}$ & $\mathbf{0}$ & $\mathbf{0}$ & $\mathbf{0}$ & 8 & 4 & 64 & 34 & العلوم \\
\hline 2594 & 294 & 236 & 319 & 308 & 340 & 343 & 403 & 351 & المجموع \\
\hline
\end{tabular}

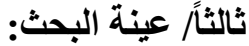

أ- عينة الكليات: نم اختبار عينة طبقية عشوائية من مجتمع الكلبات ممثل بكلية التربية الاساسية والقانون

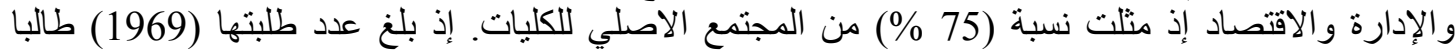
وطالبة بو اقع (937) ذكور و (1032) إناث و والجدول (2) يوضح ذلّلك.

جدول (2) عينة الكليات موزعة حسب الجنس والمرحلة الاراسية

\begin{tabular}{|c|c|c|c|c|c|c|c|c|c|}
\hline \multirow{2}{*}{ المجموع } & \multicolumn{2}{|c|}{ المرحلة الرابعة } & \multicolumn{2}{|c|}{ المرحلة الثالثة } & \multicolumn{2}{|c|}{ المرحلة الثانية } & \multicolumn{2}{|c|}{ المرحلة الاولى } & \multirow{2}{*}{ الكلية } \\
\hline & إناث & ذَكور & إناث & ذأكور & إناث & ذَكور & إناث & ذكور & \\
\hline 920 & 113 & 35 & 167 & 128 & 166 & 111 & 128 & 72 & التربية الاساسية \\
\hline 226 & $\overline{\mathbf{0}}$ & $\overline{\mathbf{0}}$ & 9 & 33 & 22 & 63 & 47 & $\overline{52}$ & القانون \\
\hline 823 & 94 & 128 & 80 & 87 & 78 & 104 & 128 & 124 & الإدارة والاقتصاد \\
\hline 1969 & 207 & 163 & 256 & 248 & 266 & 278 & 303 & 248 & المجموع \\
\hline
\end{tabular}

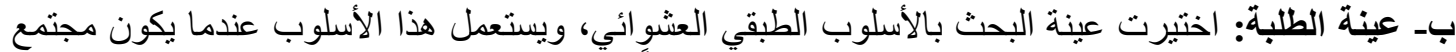

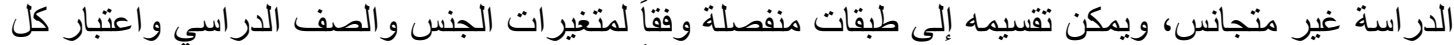

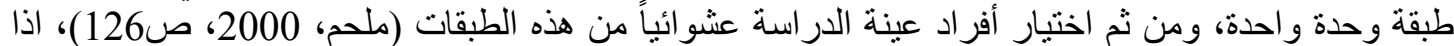

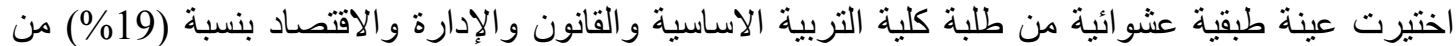
المجتمع الأصلي بلغ عددهم (500) طالبا وطالبة بو اقع (228) ذكور و (272) إناث و الجدول (3) يولة يوضح ذلانك.

جدول (3) أفراد عينة البحث الاساسية موزعين بحسب الكلية والجنس والمرحلة الاراسية

\begin{tabular}{|c|c|c|c|c|c|c|c|c|c|}
\hline \multirow{2}{*}{ المجموع } & \multicolumn{2}{|c|}{ المرحلة الرابعة } & \multicolumn{2}{|c|}{ المرحلة الثالثة } & \multicolumn{2}{|c|}{ المرحلة الثانية } & \multicolumn{2}{|c|}{ المرطلة الاولى } & \\
\hline & إناث & ذكور & إناث & ذكور & إناث & ذكور & إناث & ذاذكور & \\
\hline 250 & 39 & 23 & 40 & 30 & 35 & 25 & 33 & 25 & التربية الاساسية \\
\hline 125 & 13 & 12 & 10 & 10 & 20 & 10 & 25 & 25 & القانون \\
\hline 125 & 11 & 14 & 16 & 14 & 15 & 25 & 15 & 15 & الإدارة والاقتصاد \\
\hline 500 & 63 & 49 & 66 & 54 & 70 & 60 & 73 & 65 & المجموع \\
\hline
\end{tabular}

رابعاً : أداتا البحث : من أجل قياس المتغيرين التي يشملهم البحث الحالي هما قلق المظهر والاخفاقات المعرفية

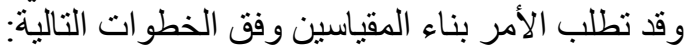
1- مقياس قلق المظهر: لغرض التعرف على مستوى فلق المظهر، ستقوم الباحثة بيناء مقياس قلق المظهر لاى 


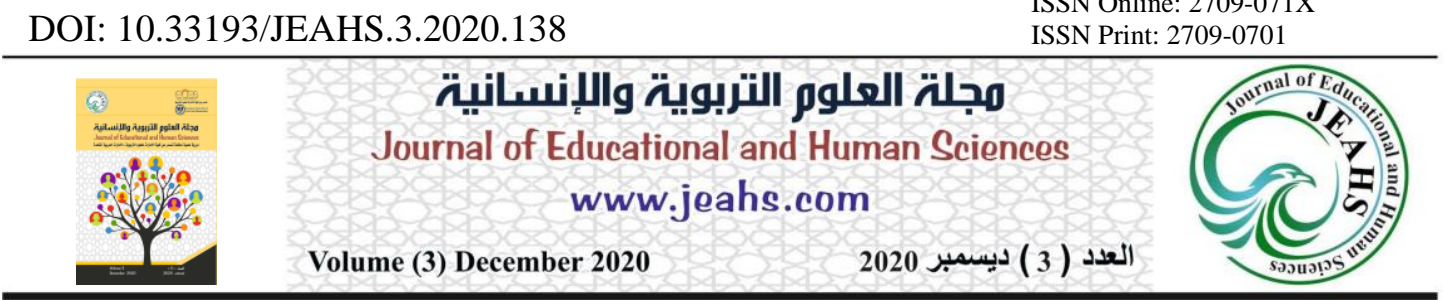

طلبة جامعة سومر، وتثير الن وين (Allen \& Yen) إلى أن عملية بناء المقياس يجب أن تمر بخطوات أساسية

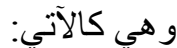

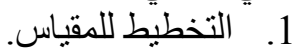

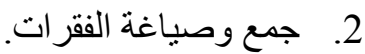
3. التأكد من صلاحية الفقر ات و والتعليمات (التحليل المنطقي للفقرات).

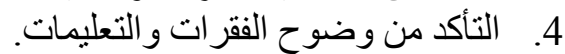
5. تطبيق الفقر ات على عينة ممثلة للمجتمع. 6. إجر اء تحليل الفقرات (Allen \& Yen, 1979, P. 118). وقد عملت الباحثة على إتباع هذه الخطوات في عملية بناء المقياس فضلاً عن استخراج خاصيتي الصدق،

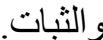

1- التخطيط لإعداد للمقياس: لغرض تحقيق هذه الخطوة اطلعت الباحثة على آر راء عدد من المفكرين، ووجهات

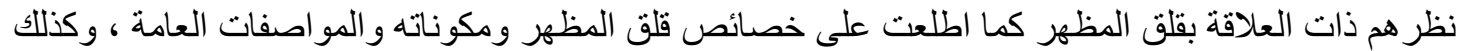

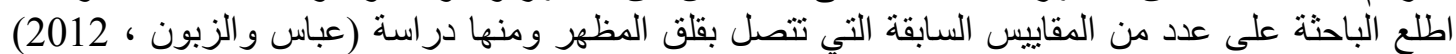

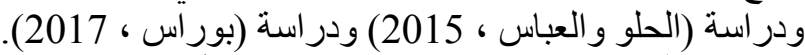

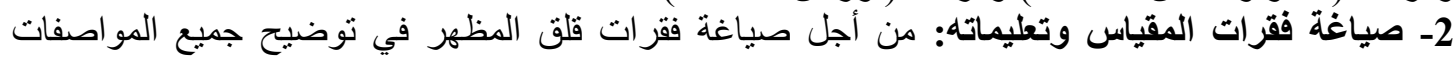

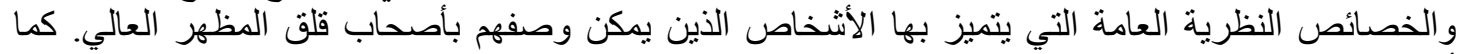

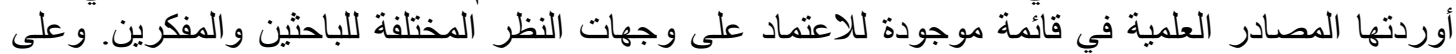

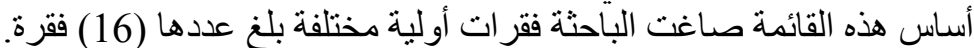

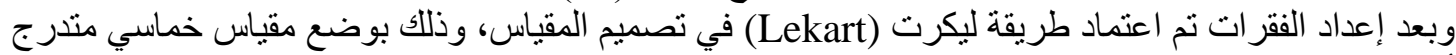

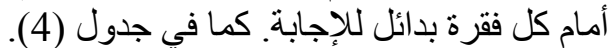
جدول (4) بدائل مقياس قلثق المظهز وأوزانه

\begin{tabular}{|c|c|c|c|c|c|c|c|}
\hline تماما تنطبق علي & غالباً تنطبق علي & ي & أحيانا ت تلبق & & غنالبًاً & & تماماً تنق \\
\hline 1 & 2 & & 3 & & 4 & & 5 \\
\hline
\end{tabular}

بعد ذلك وضعت تعليمات إلى المقياس راعت فيها الباحثة أن تكون مقتصرة وتتضنمن مثالاً يوضح كيفية

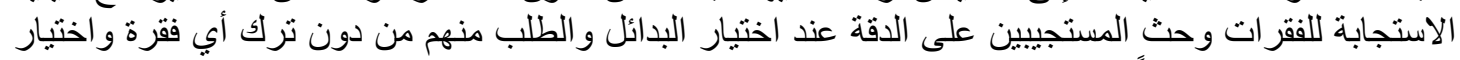

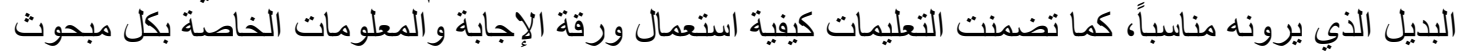

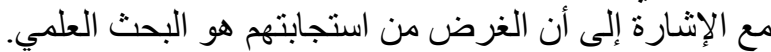
3- التأكد من صلاحية الفقرات (التحليل المنطقي للفقرات): ذكر ابيل (Ebel, 1972) أن أفضل الفيل وسيلة للتأكد

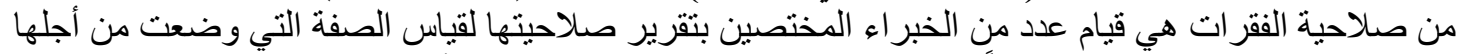

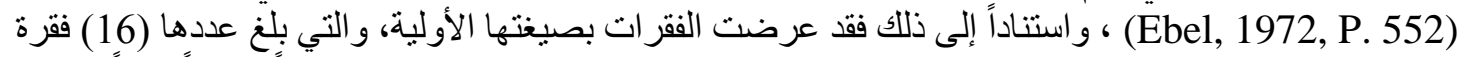

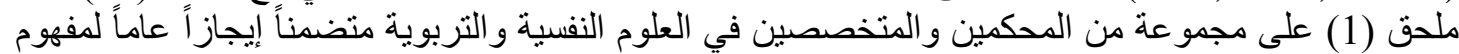

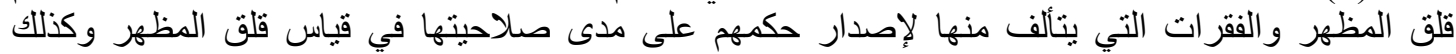

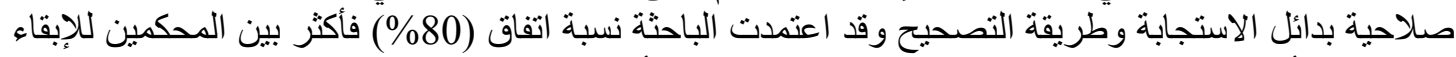

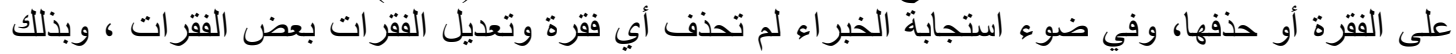

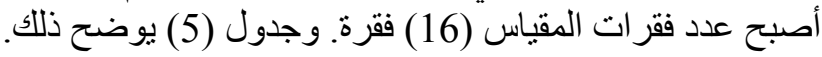




\begin{tabular}{|c|c|c|c|}
\hline \multirow{2}{*}{ 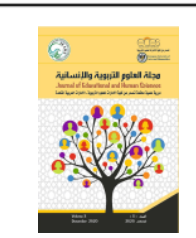 } & & \multirow{2}{*}{()$^{2}$} \\
\hline & \multicolumn{2}{|c|}{$\begin{array}{c}\text { مجلة العلور التربوية والإنسانية } \\
\text { Journal of Educational and Human Sciences } \\
\text { www.jeahs.com }\end{array}$} & \\
\hline
\end{tabular}

جدول (5) آراء المحكمين في صلاحية فقرات مقياس قلق المظهر

\begin{tabular}{|c|c|c|c|c|}
\hline \multicolumn{2}{|c|}{ 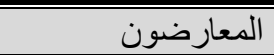 } & & المو افقو & \multirow{2}{*}{ ارقام الفقرات } \\
\hline 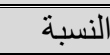 & التكرار & النسبة & التكرار & \\
\hline$\% 0.00$ & $\% 0$ & $\% 100$ & 20 & 1، 2، 3، 4، 5، 6، 7، 8، 9، 10، 11، 14، 15، \\
\hline$\% 5$ & 1 & $\% 95$ & 19 & $13 ، 12$ \\
\hline
\end{tabular}

4- التأكد من وضوح الفقرات والتطليمات: يشير فرج (1980) إلى ضرورة التحقق من مدى فهم

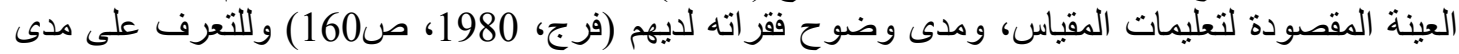

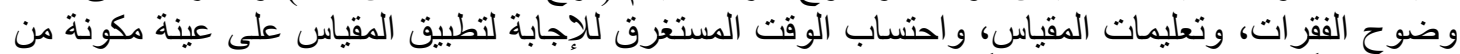

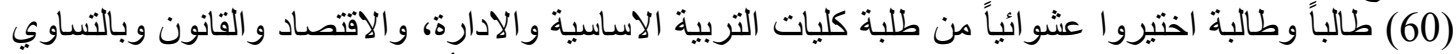

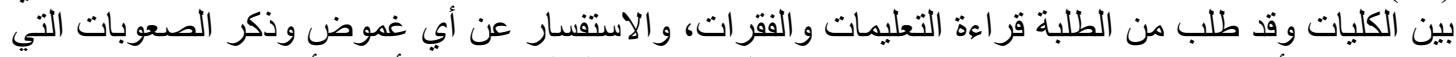

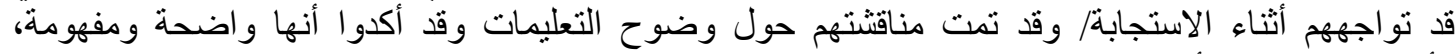

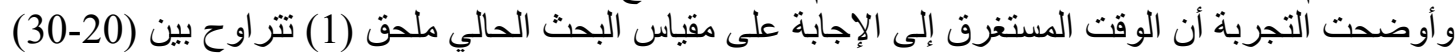
دقيقة وبمتوسط (25) دقيقة.

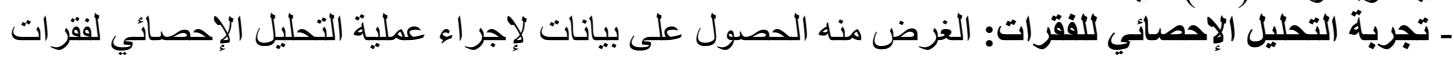

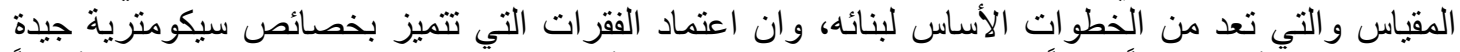

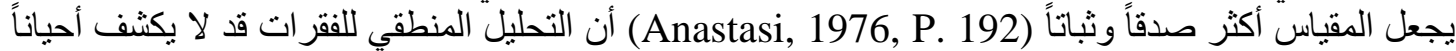

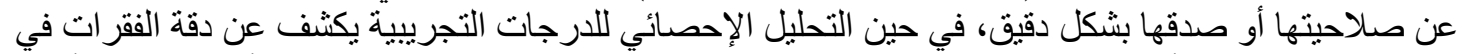

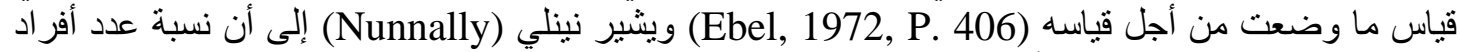

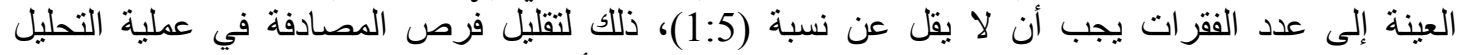

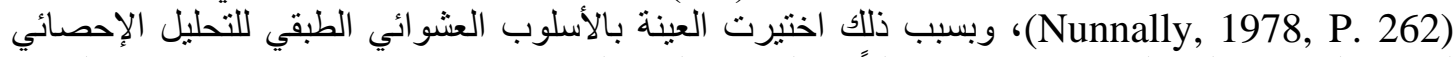

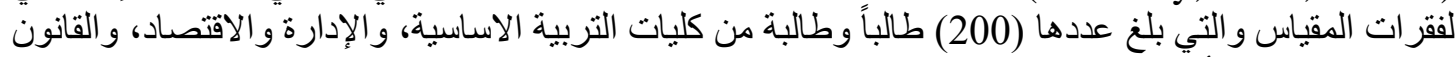

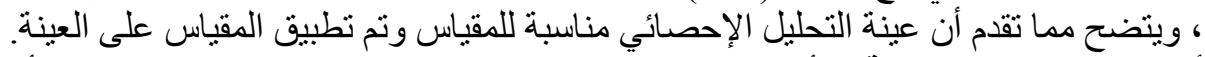

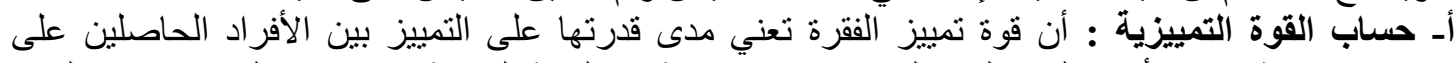

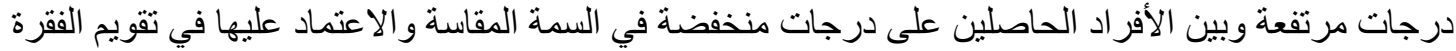

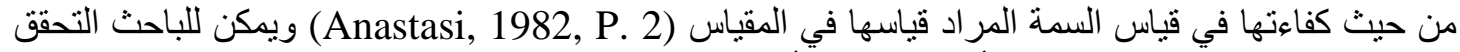

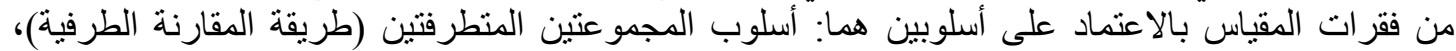

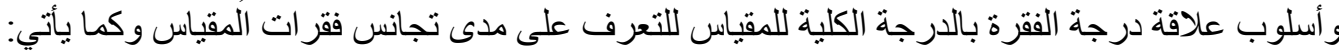

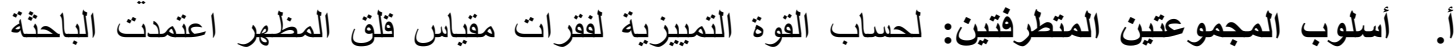

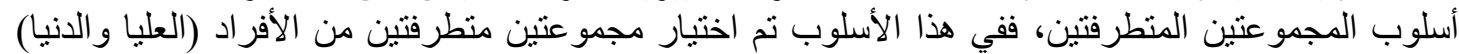

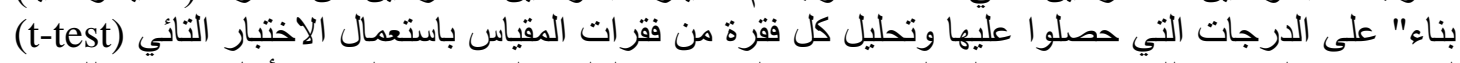

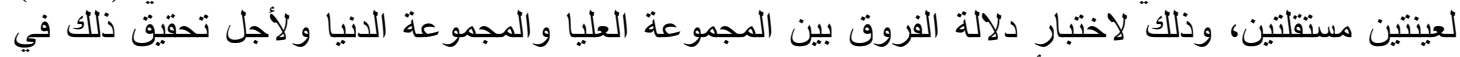

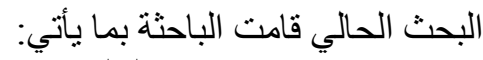
1. تصحيح الاستمار ات البالغ عددها (200) استمارة. 2.

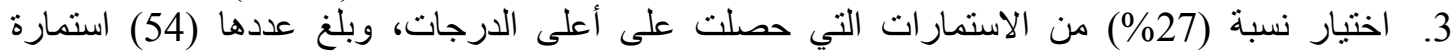

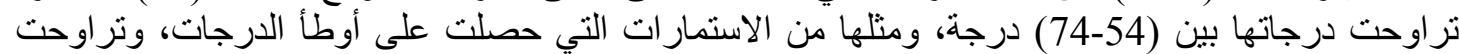

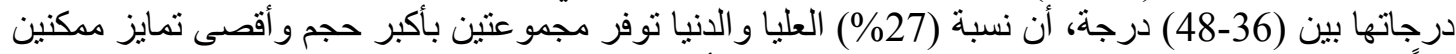

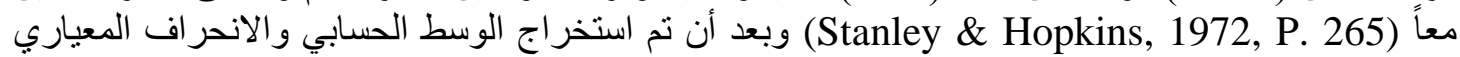
لللمجمو عتين العليا والدنيا لكل فقرة من الفقرات، قامت الباحثة بتطبيق الاختبار التائي لعينتين مستقلتين لاختئ لاختبار

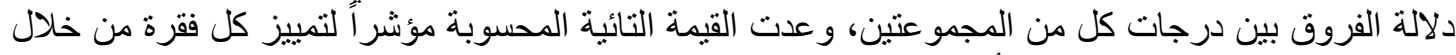

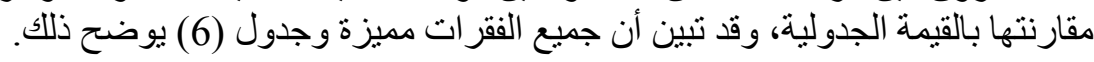




\section{مجلة العلوم التربوية والإنسانية}

Journal of Educational and Human Sciences www.jeahs.com

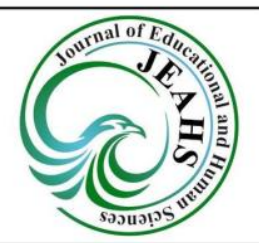

جدول (6) معامل تمييز فقرات مقياس قلق المظهر بأسلوب العينتين المتطرفتين

\begin{tabular}{|c|c|c|c|c|c|c|}
\hline \multirow{2}{*}{ الدالة مستوى الإحصائية دلائة } & \multirow[b]{2}{*}{ المحسوية التائية } & \multicolumn{2}{|c|}{ المجموعة الدنيا (ن = 54) } & \multicolumn{2}{|c|}{ المجموعة العليا (ن = 54) } & \multirow[b]{2}{*}{ لفقرة } \\
\hline & & المعياري & الحسابي & المعياري & الحسابي & \\
\hline دال إحصائيا & 5,70 & 0,92 & 3,57 & 0,77 & 4,48 & 1 \\
\hline دال إحصائيا & 7,28 & 0,99 & 3,66 & 0,54 & 4,66 & 2 \\
\hline دال إحصائيا & $\mathbf{3 , 5 7}$ & 0,94 & 3,52 & $\mathbf{0 , 9 0}$ & 4,22 & 3 \\
\hline دال إحصائيا & 5,62 & 0,94 & 4,01 & $\mathbf{0 , 5 0}$ & 4,83 & 4 \\
\hline دال إحصائيا & 4,05 & 1,13 & 3,37 & 1,00 & 4,24 & 5 \\
\hline دال إحصائيا & 6,52 & 0,96 & 3,92 & 0,40 & 4,85 & 6 \\
\hline دال إحصائيا & 4,84 & 0,96 & 3,68 & 0,76 & 4,59 & 7 \\
\hline دال إحصائيا & 3,29 & 1,09 & 4,07 & $\mathbf{0 , 7 9}$ & 4,70 & 8 \\
\hline دال إحصائيا & 7,99 & 1,05 & 2,79 & 0,87 & 4,09 & 9 \\
\hline دال إحصائيا & 7,39 & 1,15 & 3,59 & $\mathbf{0 , 5 7}$ & 4,68 & 10 \\
\hline دال إحصائيا & 7,89 & 1,16 & $\mathbf{3 , 3 3}$ & 0,48 & 4,62 & 11 \\
\hline دال إحصائيا & 6,39 & 0,99 & 3,90 & $\mathbf{0 , 5 4}$ & 4,75 & 12 \\
\hline دال إحصائيا & 2,86 & 1,03 & 4,01 & 0,81 & 4,51 & 13 \\
\hline دال إحصائيا & 5,79 & 1,03 & 3,14 & 0,91 & 4,25 & 14 \\
\hline دال إحصائيا & 5,96 & 1,11 & 2,50 & 1,15 & 3,79 & 15 \\
\hline دال إحصائيا & 8,01 & 1,06 & 3,00 & 0,81 & 4,27 & 16 \\
\hline
\end{tabular}

(") القيمة التائية الجدولية بدرجة حرية (106) عند مستوى دلالة (0,05) يساوي (2,01). ب. علاقة درجة الفقرة بالدرجة الكلية للمقياس (الاتساق الدان الداخلي)

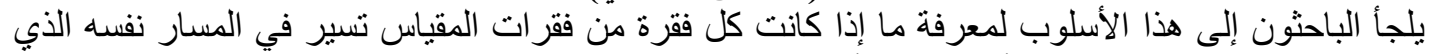

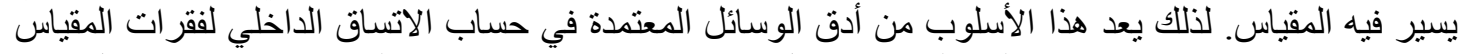

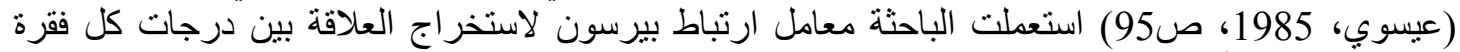

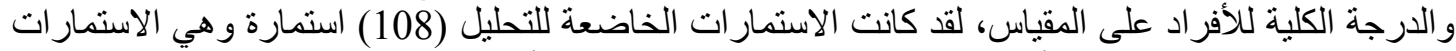

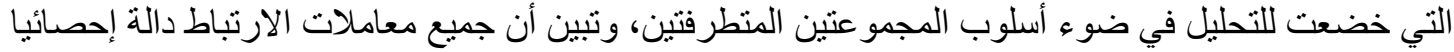
عند مستوى دلالة (0,05) وييين جدول (7) معاملات الارتباط بين كل فقرة من فقر ات ات المقياس و الدرجة الكبن الكلية

جدول (7) معاملات ارتباط الفقرة بالدرجة الكلية لمقياس قلق المظهر

\begin{tabular}{|c|c|c|c|c|c|c|c|}
\hline معامل الارتباط & 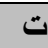 & معامل الارتباط & ت & معامل الارتباط & $\ddot{~}$ & معامل الارتباط & ت \\
\hline$* * 0,40$ & $\overline{13}$ & $* * 0,34$ & $\overline{9}$ & $\overline{* * 0,34}$ & $\overline{5}$ & $* * 0,30$ & 1 \\
\hline$* * 0,44$ & 14 & $* * 0,22$ & 10 & $* * 0,27$ & 6 & $* * 0,35$ & 2 \\
\hline$* * 0,33$ & 15 & $* * 0,45$ & 11 & $* * 0,25$ & 7 & $* * 0,32$ & 3 \\
\hline$* * 0,44$ & 16 & $* * 0,31$ & 12 & $* * 0,38$ & 8 & $* * 0,42$ & 4 \\
\hline
\end{tabular}

2- 2 مبررات مقياس الإخفاقات المعرفية.

أ- يتمتع بخصائص سايكو مترية جيدة .

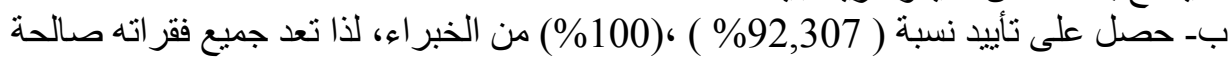

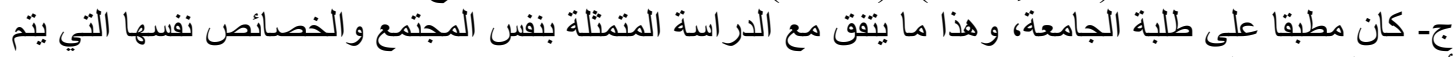
أجر اء الدر اسة عليها. 


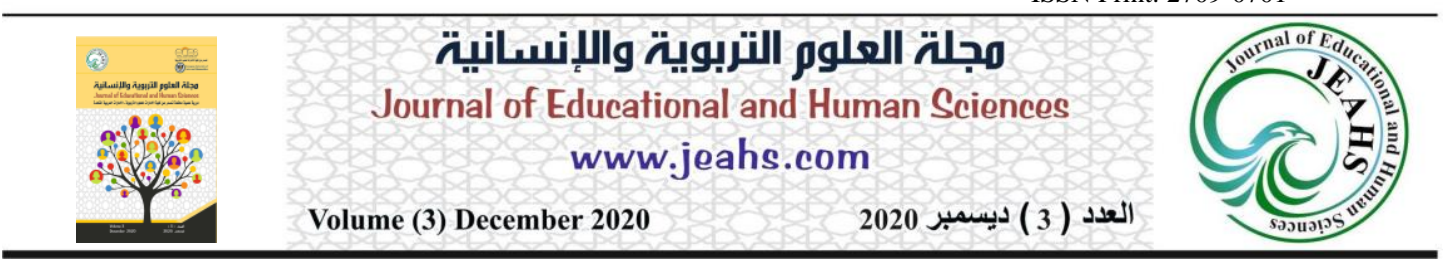

الجدول (8) النسب المئوية لإجابات السادة المحكمين على فقرات مقياس الإخفاقات المعرفية

\begin{tabular}{|c|c|c|c|c|c|c|}
\hline \multirow{2}{*}{ الكلي } & \multirow{2}{*}{ للفقرات المجموع } & \multirow{2}{*}{ النسبة المئوية } & \multicolumn{2}{|r|}{ الخبراء } & \multirow{2}{*}{ الفقرات } & \multirow{2}{*}{ الفقرات } \\
\hline & & & غير الموافقون & الموافقون & & \\
\hline \multirow{2}{*}{\multicolumn{2}{|c|}{25}} & $\% 100$ & - & 13 & 15 & $1,2,3,4,5,6,7,8,9,10,11,12,13,14,15$ \\
\hline & & $92,307 \%$ & 1 & 12 & 10 & $16,17,18,19,20,21,22,23,24,25$ \\
\hline
\end{tabular}

و عليه أصبحت جميع فقر ات المقياس صالحة ،حسب آراء المحكمين، ومجموع فقرات المقياس (25) فقرة كما

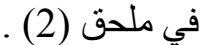

3- اعداد تعليمات المقياس: وضعت الباحثة تعليمات لمقياس الاخفاقات المعرفية ملحق (2)، التي تضمنت كيفية

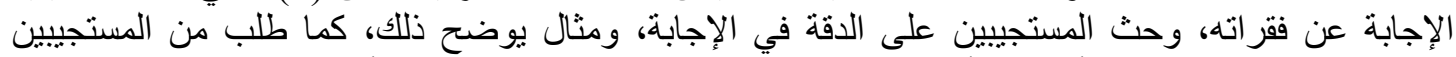

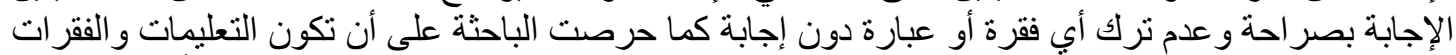

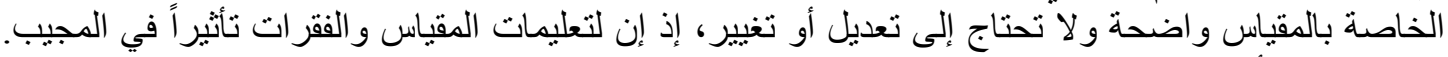

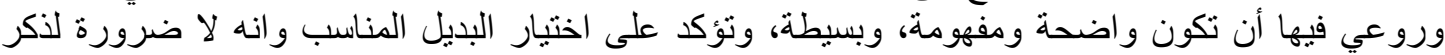

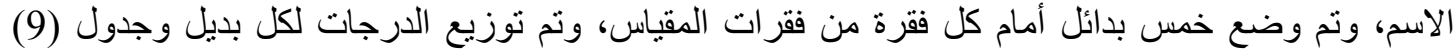

جدول (9) بدائل مقياس الاخفاقات المعرفية وأوزانه

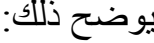

\begin{tabular}{|c|c|c|c|c|c|}
\hline \multicolumn{5}{|c|}{ الاخفاقات المعرفية } & \multirow[b]{2}{*}{ بدائل المقياس } \\
\hline لا تنطبق عليّ أبداً & تنادراً & أحياناً & غنطبقِ عليّ & تنماماً ت عليّ & \\
\hline 1 & 2 & 3 & 4 & 5 & الأوزان \\
\hline
\end{tabular}

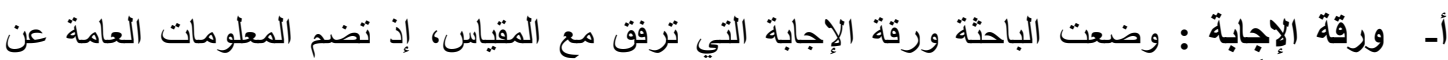

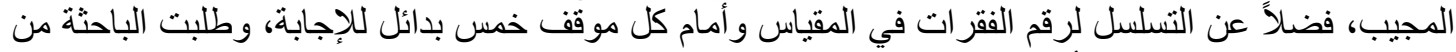

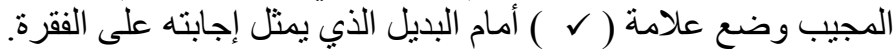

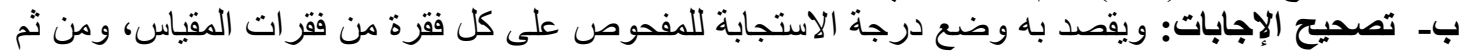

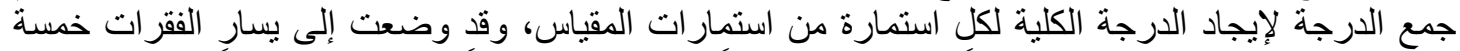

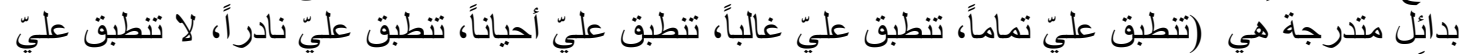

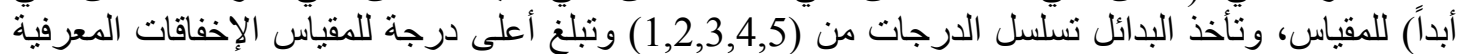

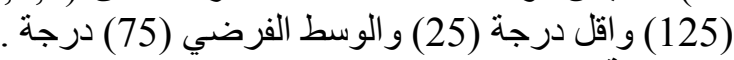

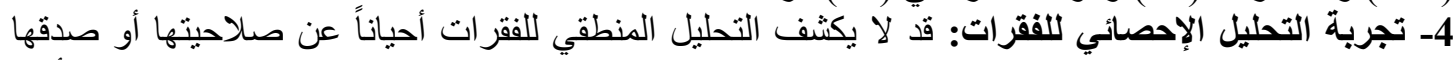

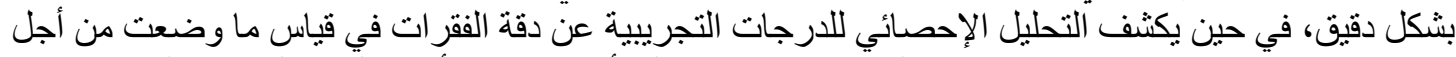

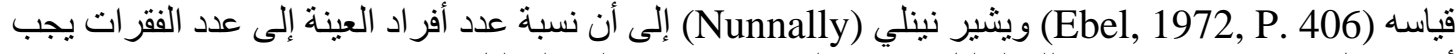

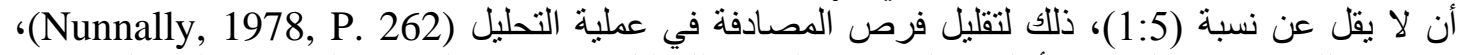

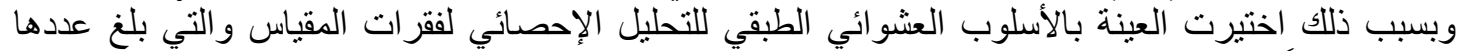

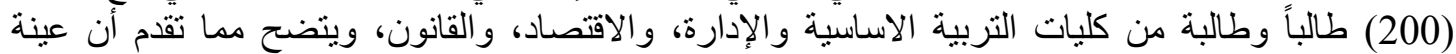

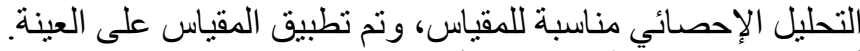

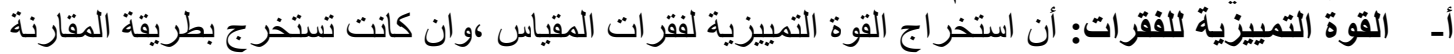

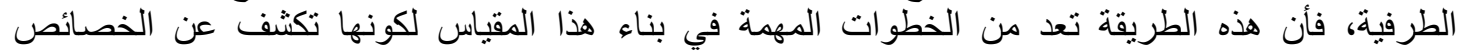

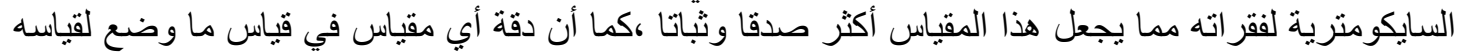

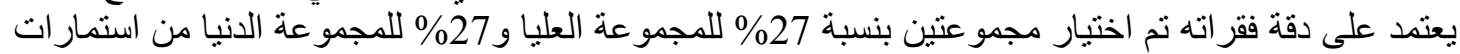

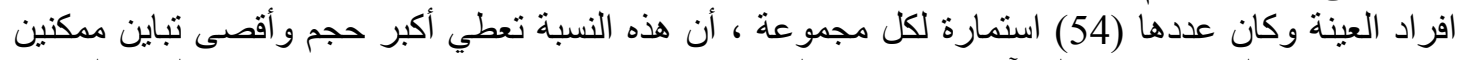

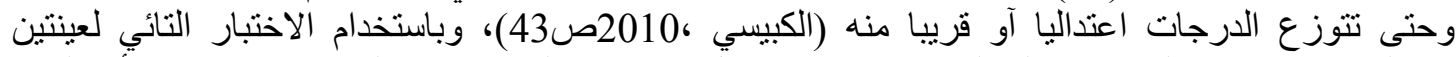
مستقلتين (T-Test) لمعرفة دلاله الفرق في درجات كل فقرة بين المجموعتين المنطرفتين ،اتضح أن القيان القيمة 


\section{مجلة العلوم التربوية والإنسانية}

ast?

Journal of Educational and Human Sciences

www.jeahs.com

العدد ( 3 ) ديسمبر 2020

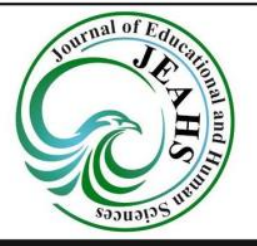

التائية المحسوبة لجميع فقرات مقياس الإخفاقات المعرفية مميزة عند مستوى دلاله (10,05) ودرجة حرية (106) لان القيمة التائية المحسوبة أعلى من القيمة الجدولية (1,98) والجدول $(10)$ يوضح معاملات تمييز فقرات

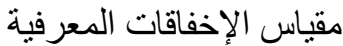

الجدول (10) معاملات تمييز فقرات الإخفاقات المعرفية بأسلوب المجموعتين المتطرفتين

\begin{tabular}{|c|c|c|c|c|c|c|}
\hline \multirow{2}{*}{ مستوى $\quad$ الدلالة } & \multirow{2}{*}{ القحسوبة $\quad$ التائية } & \multicolumn{2}{|c|}{ المجموعة الدنيا(54) } & \multicolumn{2}{|c|}{ المجموعة العليا(54) } & \multirow[b]{2}{*}{$ت$} \\
\hline & & الالتحرافياري & الكسابي & الالمعراف & الوسابي & \\
\hline دال إحصائيا & 2,748 & 0,93 & 3,62 & 0,856 & 4,05 & 1 \\
\hline دال إحصائيا & 3,373 & 1.16 & 2,45 & 1,282 & 3,17 & 2 \\
\hline دال إحصائيا & 5,692 & 1,008 & 3,28 & 0,833 & 4,2 & 3 \\
\hline دال إحصائيا & 5,171 & 1,374 & 2,95 & 1,161 & 4,11 & 4 \\
\hline دال إحصائيا & 7,621 & 1,068 & 3,02 & 0,801 & 4,28 & 5 \\
\hline دال إحصائيا & 7,511 & 1,074 & 3,14 & 0,825 & 4,4 & 6 \\
\hline دال إحصائيا & 8,693 & 1,068 & 3,02 & 0,812 & 4,46 & 7 \\
\hline دال إحصائيا & $\mathbf{8 , 0 5 7}$ & 0,906 & 3,74 & 0,493 & 4,77 & 8 \\
\hline دال إحصائيا & 6,251 & 0,98 & 3,29 & 0,776 & 4,26 & 9 \\
\hline دال إحصائيا & 9,012 & 1,117 & 2,69 & 0,78 & 4,33 & 10 \\
\hline دال إحصائيا & 6,016 & 1,111 & 3,22 & 0,786 & 4,23 & 11 \\
\hline دال إحصائيا & 7,144 & 1,008 & 2,98 & 0,852 & 4,15 & 12 \\
\hline دال إحصائيا & 2,355 & 1,121 & 3,2 & 1,037 & 3,65 & 13 \\
\hline دال إحصائيا & $\overline{9,586}$ & 0,932 & 3,4 & 0,533 & 4,68 & 14 \\
\hline دال إحصائيا & 6,454 & 1,16 & 3,25 & 0,823 & 4,38 & 15 \\
\hline دال إحصائيا & 7,065 & 1,068 & 3,28 & 0,77 & 4,43 & 16 \\
\hline دال إحصائيا & 7,903 & 1,107 & 3,2 & 0,687 & 4,48 & 17 \\
\hline دال إحصائيا & 6,740 & 0,917 & 3,69 & 0,581 & 4,6 & 18 \\
\hline دال إحصائيا & 5,061 & 0,884 & 3,25 & 0,883 & 4,03 & 19 \\
\hline دال إحصائيا & 6,809 & 1,14 & 3,17 & 0,878 & 4,38 & 20 \\
\hline دال إحصائيا & 4,704 & 0,945 & 3,29 & 0,945 & 4,17 & 21 \\
\hline دال إحصائيا & 10,357 & 0,965 & 2,77 & 0,825 & 4,4 & 22 \\
\hline دال إحصائيا & 4,000 & 1,017 & 3,54 & 1 & 4,25 & 23 \\
\hline دال إحصائيا & 4,815 & 1,147 & 3,49 & 0,997 & 4,4 & 24 \\
\hline دال إحصائيا & 5,185 & 1,008 & 3,72 & 0,687 & 4,51 & 25 \\
\hline
\end{tabular}

بـ علاقة درجة الفقرة بالدرجة الكلية للمقياس (الاتساق الداخلي): عادة يلجأ الباحثون إلى هذا الأسلوب

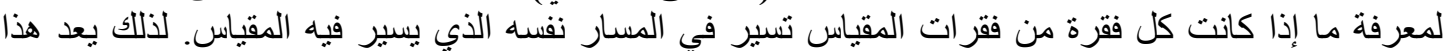

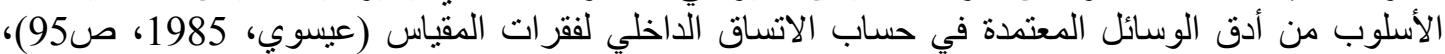

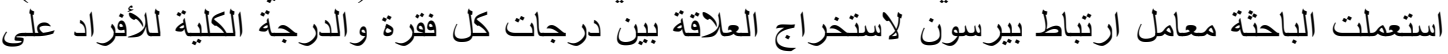

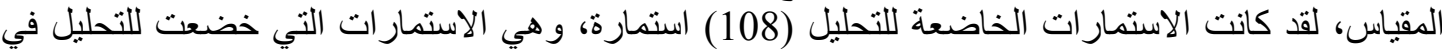
ضوء أسلوب المجموعتين المتطرفتين، وتبين أن جميع معاملات الارنباط دالة إحصائيا عند مسنوى دلالة التاني 


\section{مجلة العلوم التربوية والإنسانية}

Journal of Educational and Human Sciences www.jeahs.com

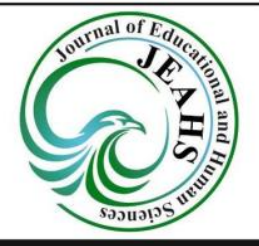

(0,05) ويبين جدول (11) معاملات الارتباط بين كل فقرة من فقرات المقياس و الدرجة الكلية للمقياس.

جدول (11) معامل ارتباط درجة كل فقرة بالمقياس بالارجة الكلية لمقياس الإخفاقات المعرفية

\begin{tabular}{|c|c|c|c|c|c|c|c|c|c|}
\hline معامل & ت & معامل & $ت$ & معامل الارتباط & $ت$ & معامل & ت & معامل & ت \\
\hline 0,856 & 21 & 0,792 & 16 & 0,732 & 11 & 0,547 & $\overline{66}$ & 0,738 & 1 \\
\hline $0,8,860$ & 22 & 0,897 & 17 & 0,856 & 12 & 0,543 & 7 & 0,806 & 2 \\
\hline $\begin{array}{c}0,864 \\
\end{array}$ & 23 & 0,912 & 18 & 0,937 & 13 & 0,783 & 8 & 0,845 & 3 \\
\hline 0,792 & 24 & 0,892 & 19 & 0,515 & 14 & 0,748 & 9 & 0,778 & $\overline{4}$ \\
\hline 0,897 & 25 & 0,844 & 20 & 0,864 & 15 & 0,775 & 10 & 0,458 & 5 \\
\hline
\end{tabular}

ويتضح من الجدول أعلاه أن جميع معاملات الارتباط دال إحصائيا عند مستوى دلالة (0,05) لفقرات مقياس

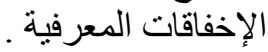

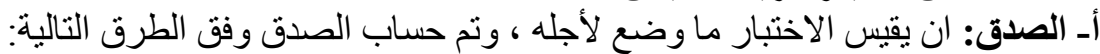

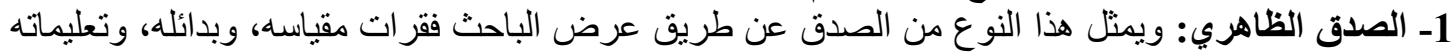

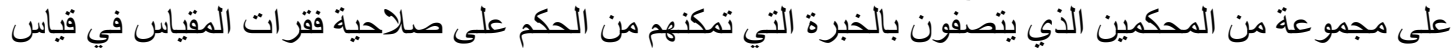

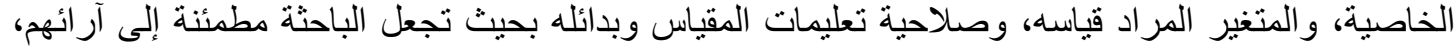

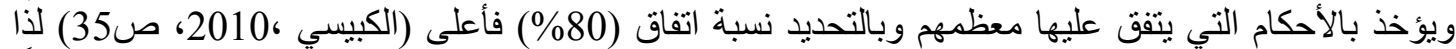

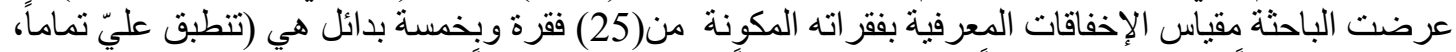

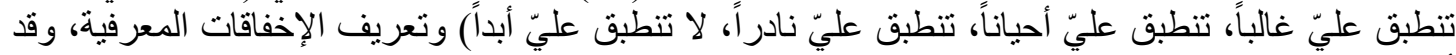

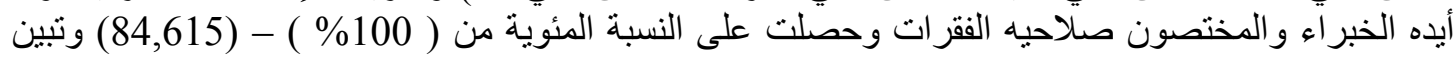

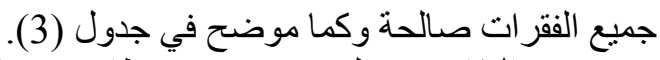

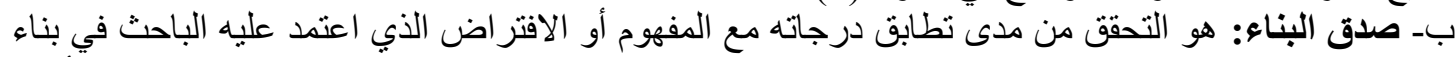

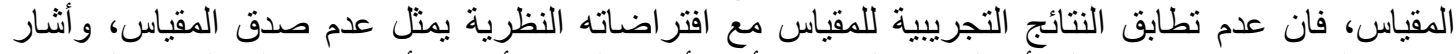

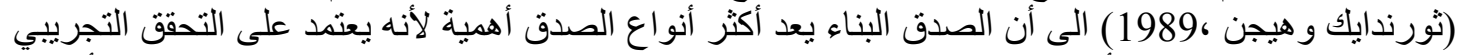

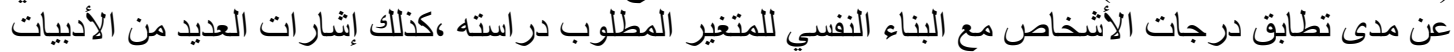

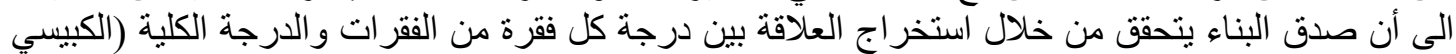

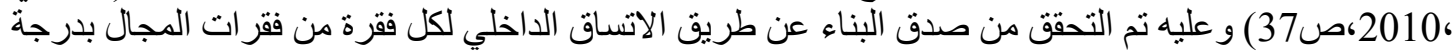

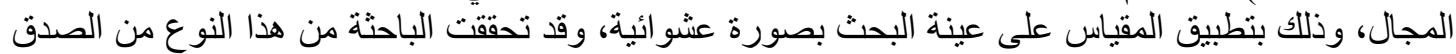

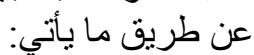

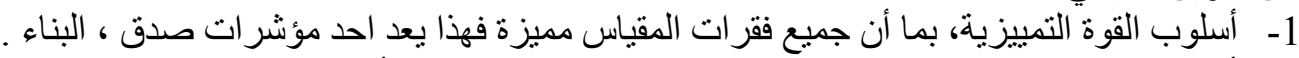

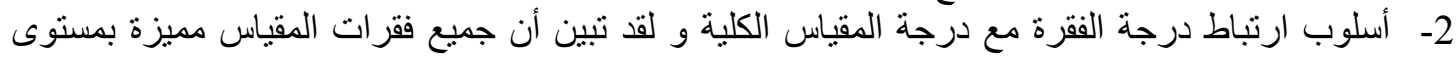

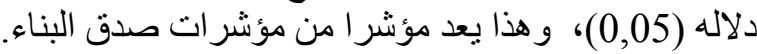
بـ الثبات: نم حساب ثبات منات مقياس (الاخفاقات المعرفية) بطريقتنين هما: (طريقة الاختبار - إعادة الاختبار وطريقة ألفا-كرونباخ).

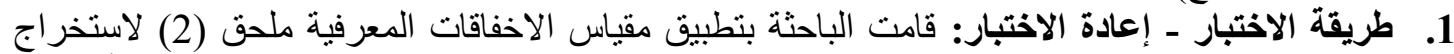

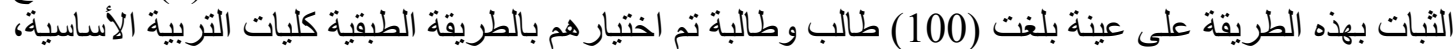

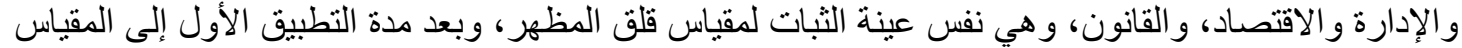

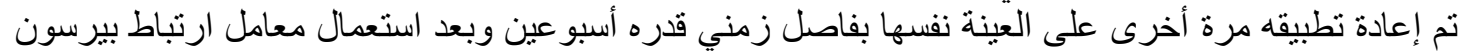

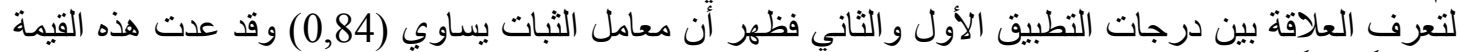

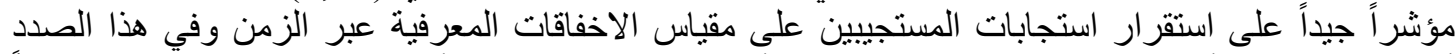

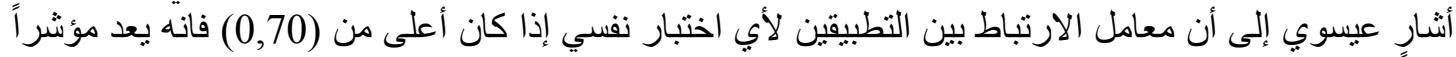

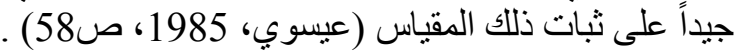




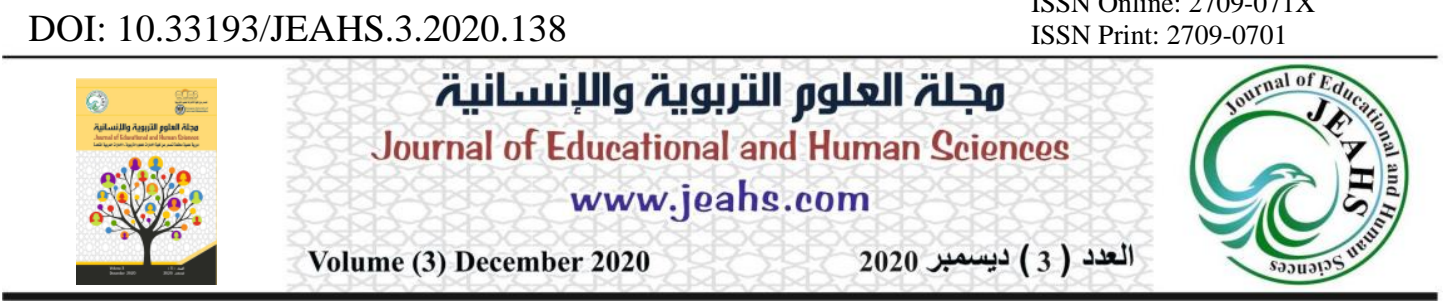

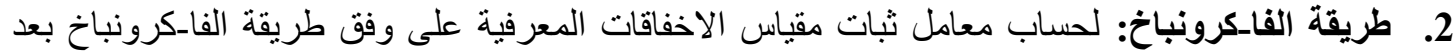

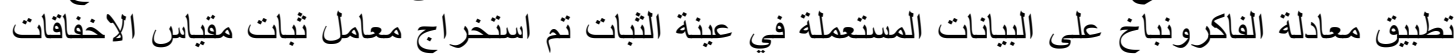

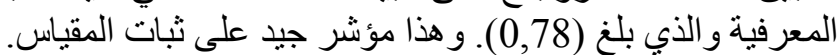

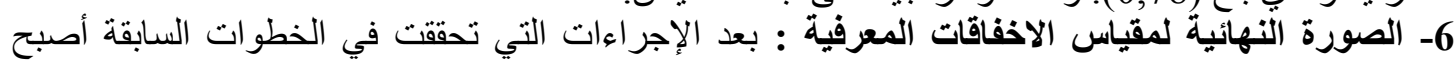

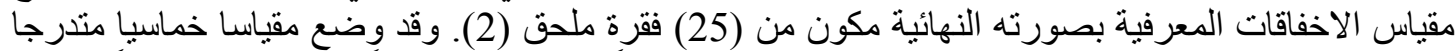

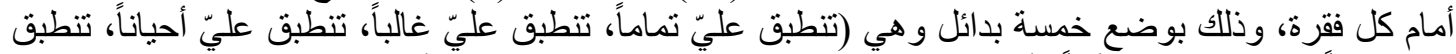

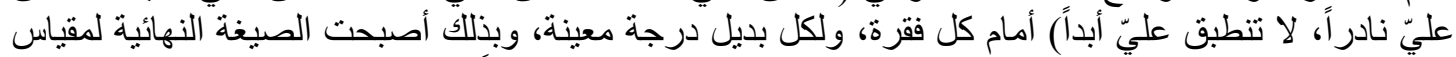

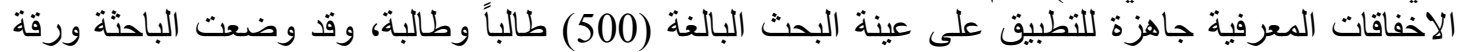

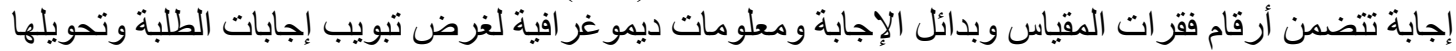

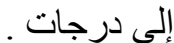

خامساً: التطبيق النهائي للمقياسين: بعد أن تم بناء مقياس قلق المظهر، ومقياس الاخفاقات المعرفية، وبهدف

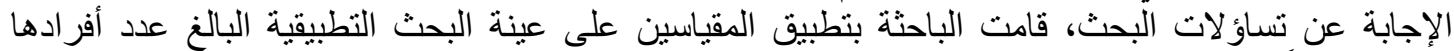

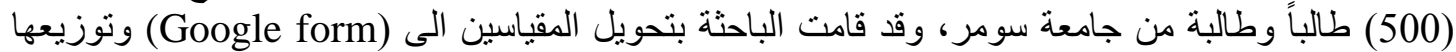

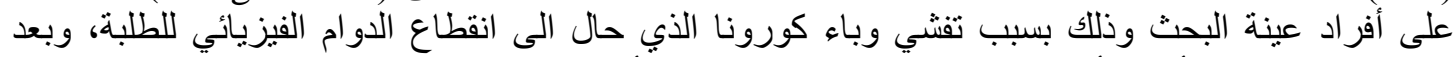

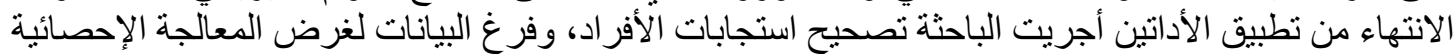
عبر استعمال الحقيبة الإحصائية للعلوم الاجتماعية الإنية (SPSS).

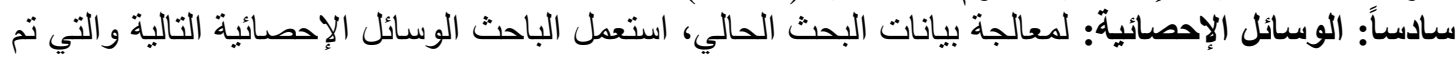

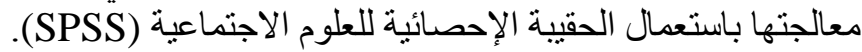

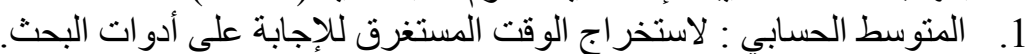

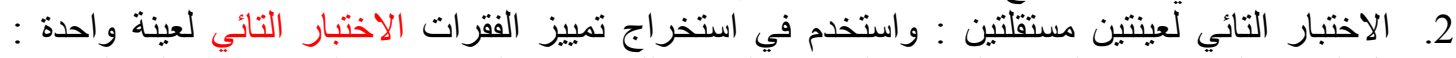

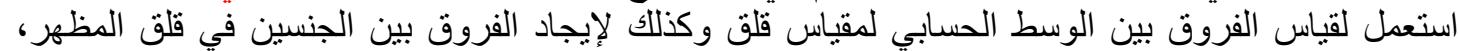

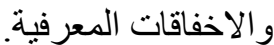

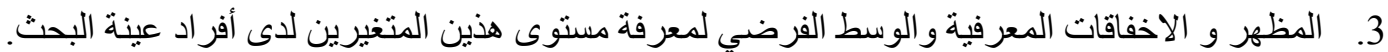

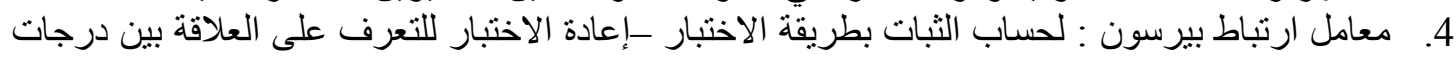

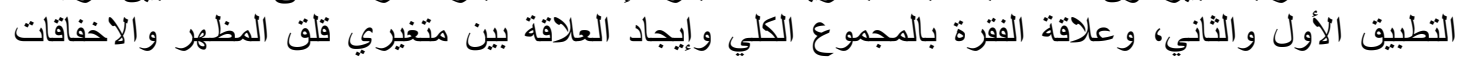

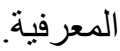

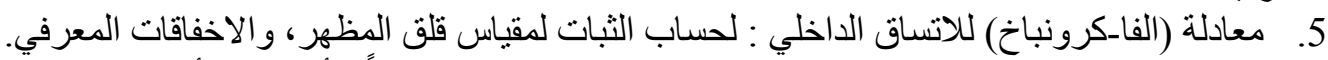

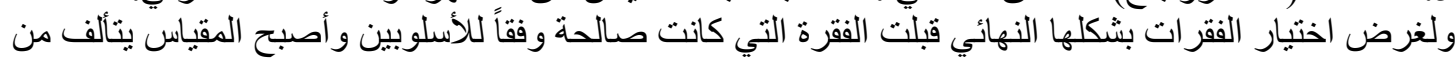

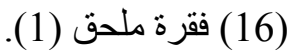

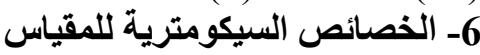

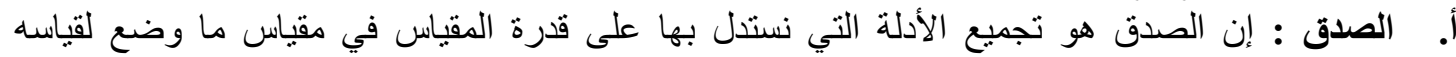
(Anastasi, 1976, P. 134) ، قامت الباحثة باستخر اج الصدق الظاهري وصدق البناء البناء لمقياس قلق المظهر كما يأتي:

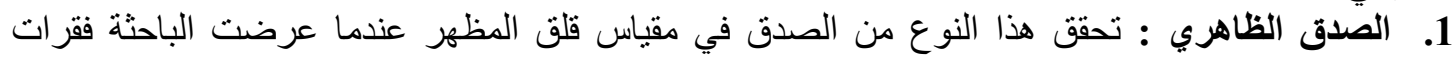

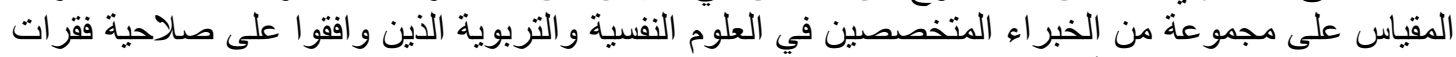

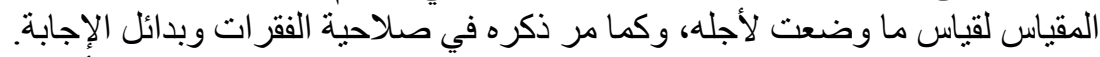

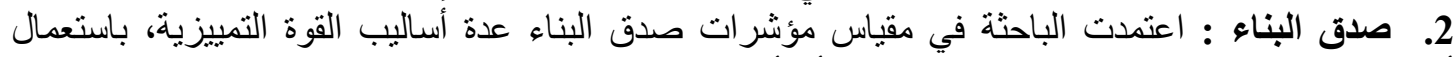

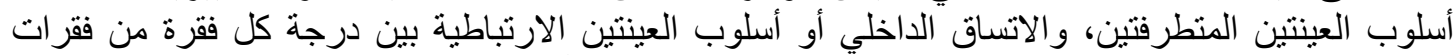

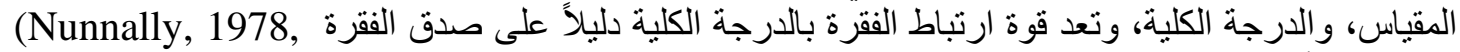
Pأظظهرت هذه الارتباطات دلالة إحصائية مناسبة.

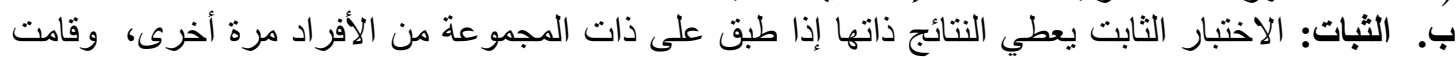

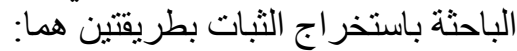
1. طريقة الاختبار- إعادة الاختبار: تحققت الباحثة من ثبات المقياس عن طريق تطبيق المقياس على عينة بلغ 


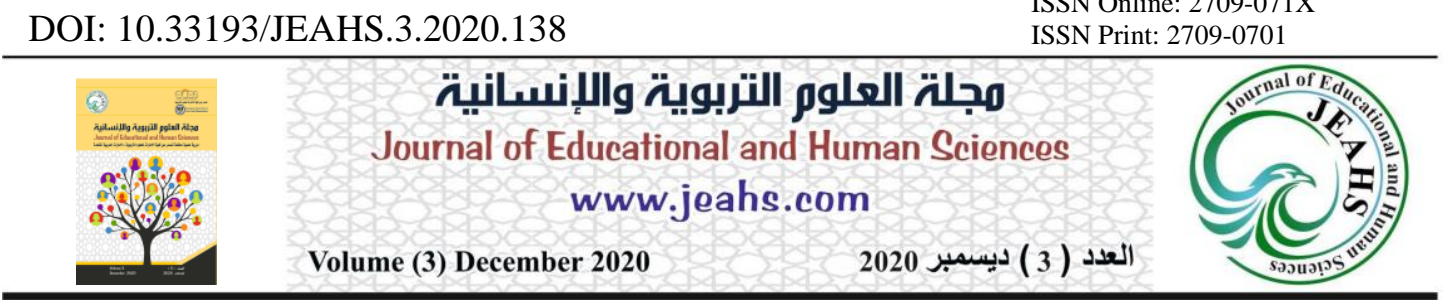

عدد أفرادها (100) طالب وطالبة اختيروا بطريقة الطبقية العشوائية في كليات التربية الأساسية، والادارة،

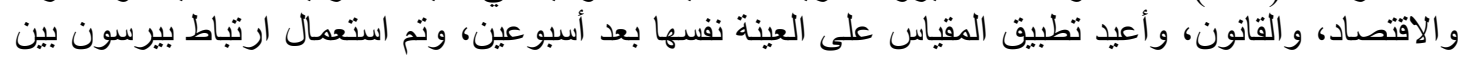

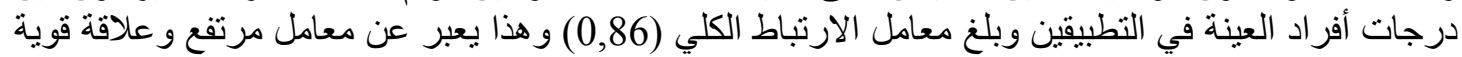

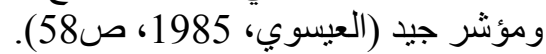

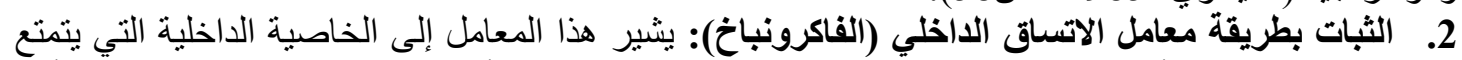

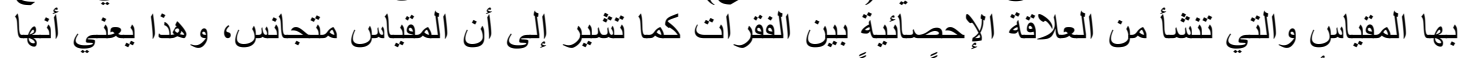

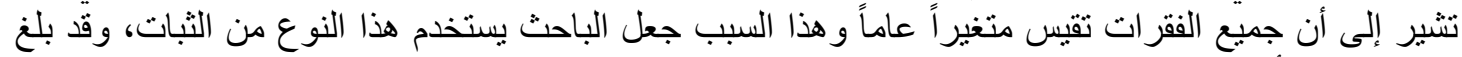

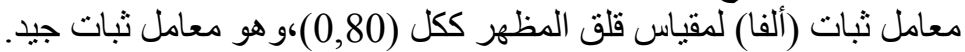
7- الصورة النهائية لمقياس قلقئ المقاس المظهر:

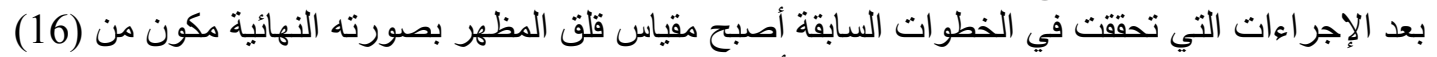

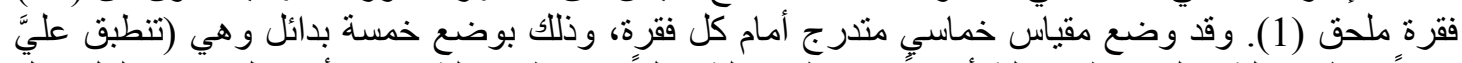

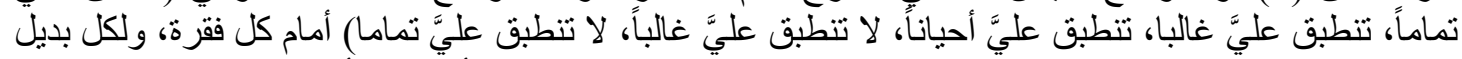

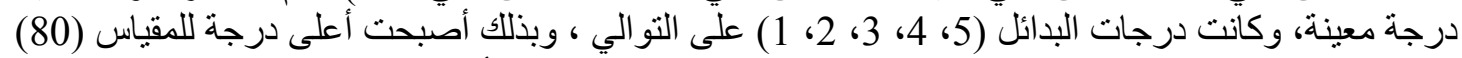

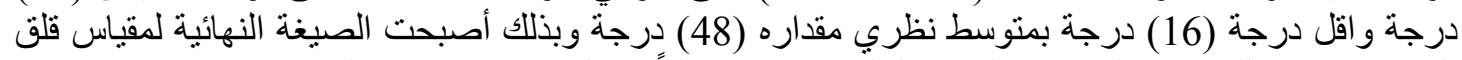

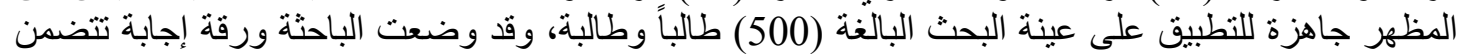

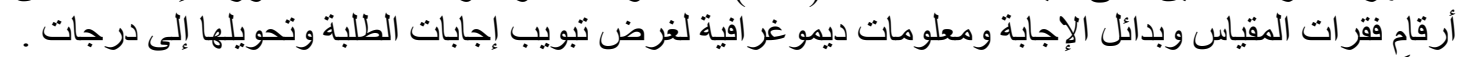

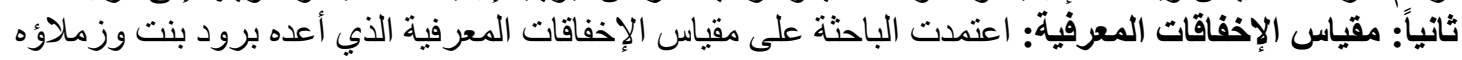

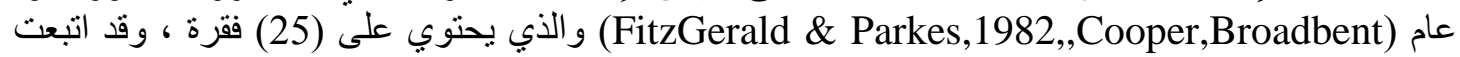

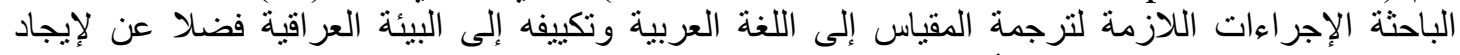

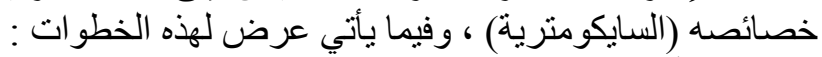
1 أ - ترجم مقياس الإخفاقات المعرفية من اللغة الإنكليزية إلى اللغة العربية، وتم الحصول على ترجمتين، ومن ثم

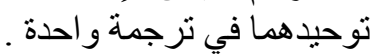

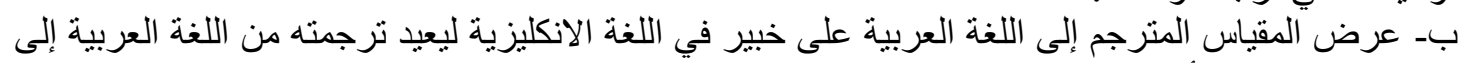

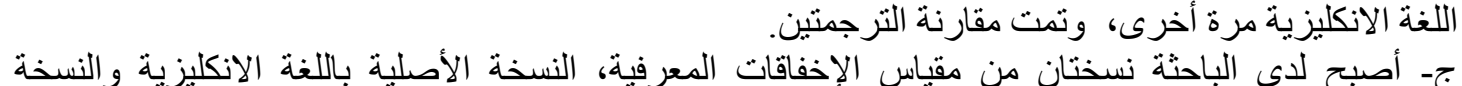
المترجمة من العربية إلى الباحثة الانكليزية.

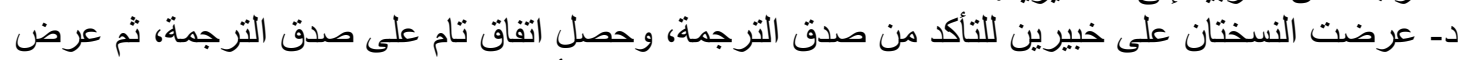

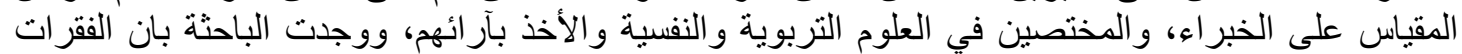

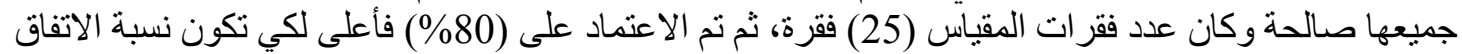

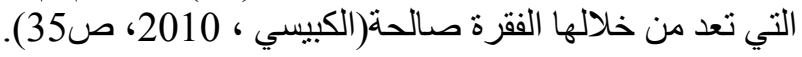

\section{الفصل الرابع: عرض النتائج ومناقشتها وتفسيرها}

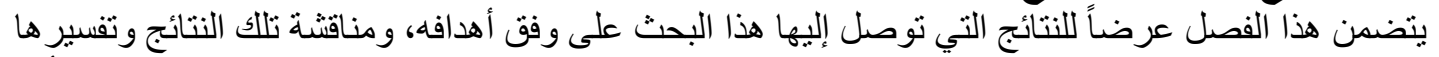

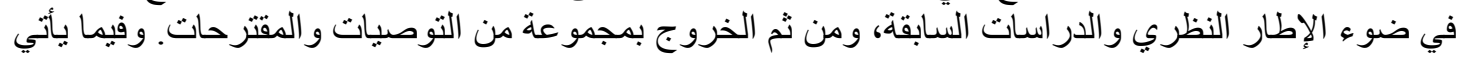

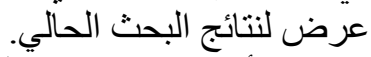
الهدف الأول: التعرف على قلى البح المظهر لدى طلبة جامعة سومر.

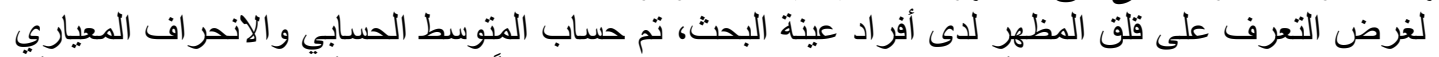

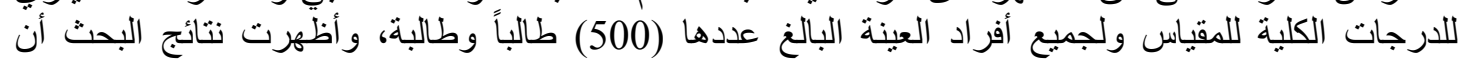

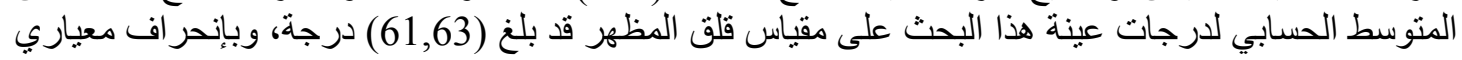




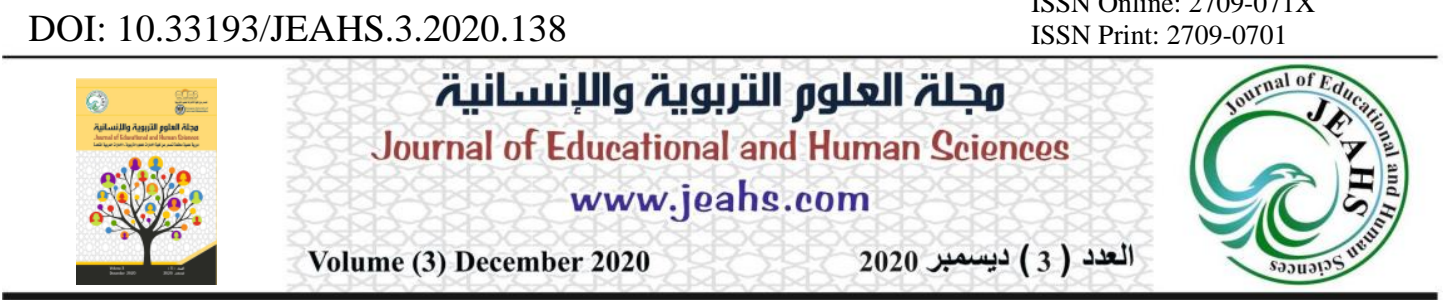

قدره (22,72) درجة وعند مقارنة المتوسط الحسابي بالمتوسط الفرضي(1*) للمقياس الذي بلغ (48) درجة، وباستعمال معادلة الاختبار التائي لعينة واحدة كانت النتائج بالثكل الذي بوني يوضحه الجدول (12)

جدول (12) نتائج الاختبار التائي لعينة واحدة للتعرف على مستوى قلق المظهر لاى أفراد العينة

\begin{tabular}{|c|c|c|c|c|c|c|}
\hline الدلالة الإحصائية 0,05 & القحسوبة التائية & الحرية & الفرضي & الانحياري & الصستوسطي & العينة $\quad$ أفزاد \\
\hline الفرق دال احصائياً & 13,414 & $\overline{499}$ & 48 & 22,72 & 61,63 & $\overline{500}$ \\
\hline
\end{tabular}

تبين من النتائج أعلاه في جدول (12)، أن الفرق دال إحصائيا بين المتوسط الحسابي والمتوسط الفرضي

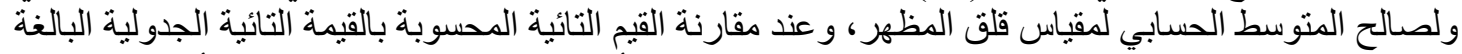

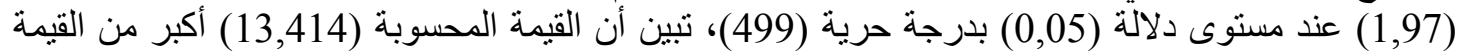

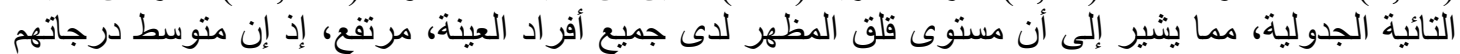

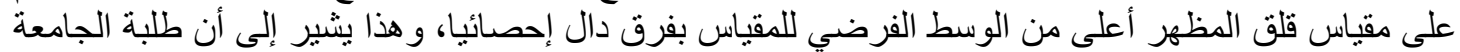

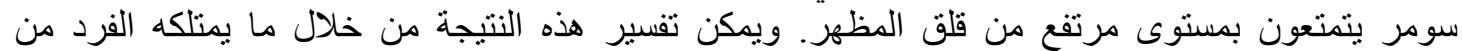

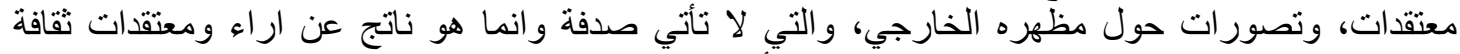

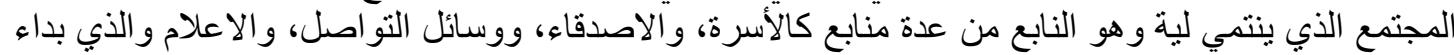

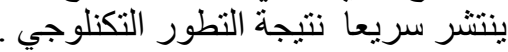
الهاف الثاني: التعرف على الفرق في قلق المظهر على وفق متغير الجنس (ذكور، إناث).

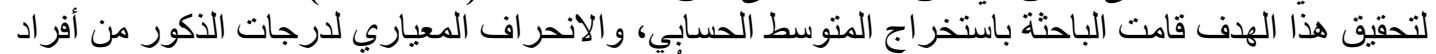

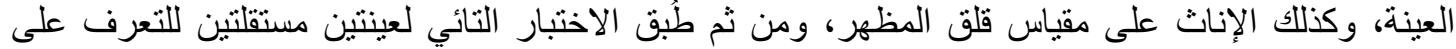
الفروق بين الجنسين (ذكور ، إناث) في قلق المظهر وجنان وندول (13) يوضح ذللك.

جدول (13) الاختبار التائي لعينتين لإيجاد الفرق بين الجنسين في قلق المظهر

\begin{tabular}{|c|c|c|c|c|c|c|}
\hline عند مستوى الإحصائية & القحسوبة التيمة التئة & درجة الحرية & الالاتحرافي & الحسابي & العدد & انطلبة \\
\hline \multirow{2}{*}{ الفرق دال احصائياً } & \multirow{2}{*}{4,344} & \multirow[b]{2}{*}{498} & 18,22 & 66,37 & 272 & إناث \\
\hline & & & 25,26 & 57,66 & 228 & دكور \\
\hline
\end{tabular}

يتبين من النتائج أعلاه في جدول (13) أنه إذ كانت القيمة التائية المحسوبة (4,344) اكبر من القيمة الجدولية

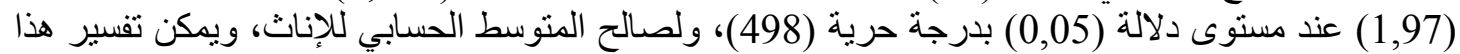

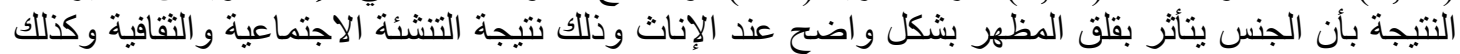

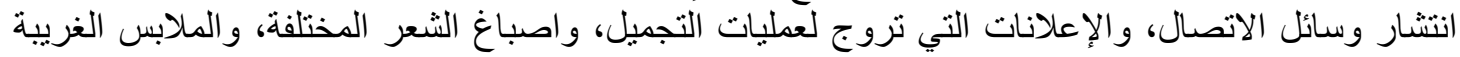
وهذه النتيجة تتفق مع دراسة (Margraf \& Rudolf, 1999) التي تؤكد زيادة نسبة قلق المظهر التهر عند الإناث اكثر مما عند الرجال ، وكذللك اتفقت نتائج الدراسة مع أبحاث كل من (Thonpson \& Chad , 2002 ) و فالمر أة في المجتمع العر اقي تشعر بقلق مظهر ها تحاثنياً من الانتقادات (Krane \& Michalenok , 2001) ولكي يبدون اكثر جاذبية.

الهذف الثالث: التعرف على مستوى الاخفاقات المعرفية لاى طلبة جامعة سومر.

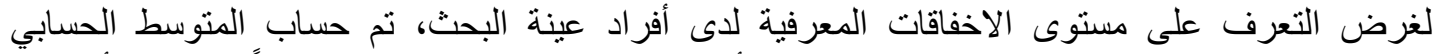
و الانحر اف المعياري للارجات الكلية للمقياس ولجميع أفر اد العينة البالغ عددها (500) طالباً وطالبة، و أظهرت 11(*) تم استخر اج المتوسط الفرضي لمقياس قلق المظهر وذلك من خلال مجموع اوزان البدائل ؛ عدد البدائل × عدد الفقر ات البالغة (16) فقرة يصبح اللوسط الفرضي (48). 


\section{مجلة العلوم التربوية والإنسانية}

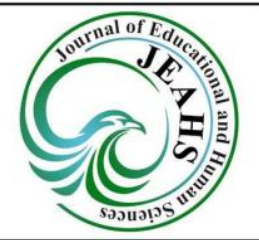

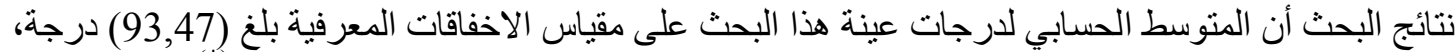

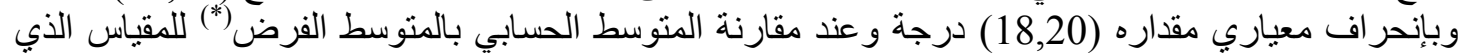

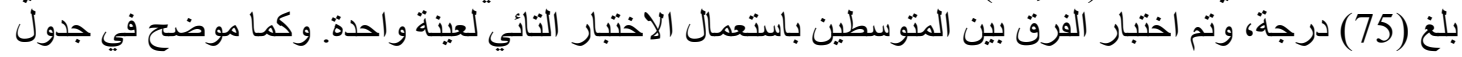

جدول (14) الاختبار التائي لعينة واحدة للتعرف على مستوى الاخفاقات المعرفية لدى طلبة الجامعة

\begin{tabular}{|c|c|c|c|c|c|c|}
\hline الالالة & |القحسية & الفرضي & جة الحرية & الالعياري & الحسابي & العينة أفراد \\
\hline الفرق دال احصائياً & 22,69 & 75 & 499 & 18,20 & 93,47 & 500 \\
\hline
\end{tabular}

يتبين من النتائج أعلاه في جدول (14) أن الفرق دال إحصائيا بين المتوسط الحسابي و المتوسط الفرضي العيدي

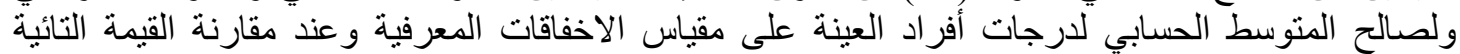

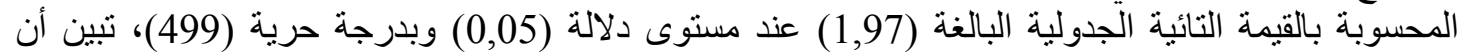

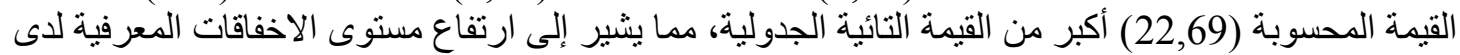

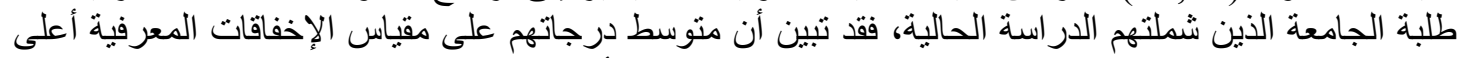

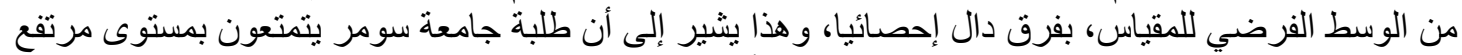

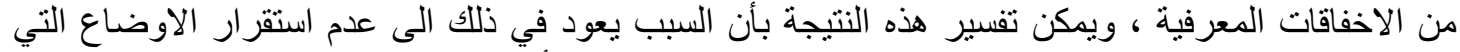

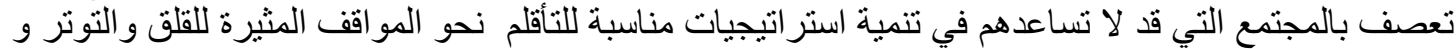

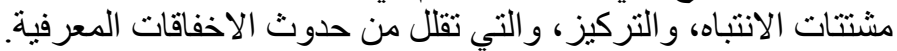

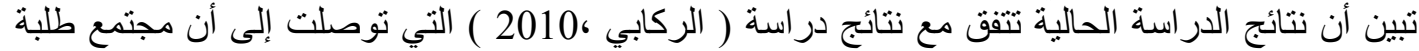

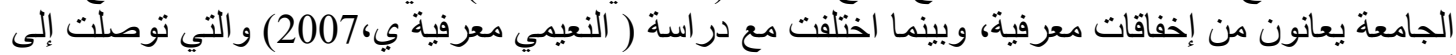
أن طلبة الجامعة لا يعانون من الإخفاقات المعرف المعرفية. الهدف رابع: التعرف على الفرق في مستوى الاخفاقات المعرفية على وفق متفير الجنس

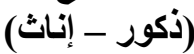

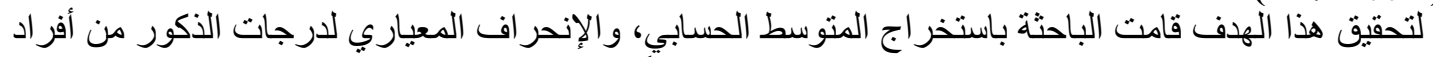

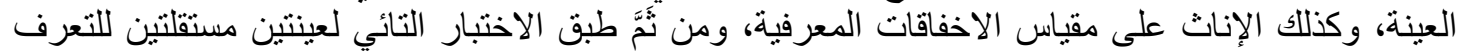
على الفروق بين الجنسين (ذكور، إناث) في الاخفاقات المعرفية ، فكانت النتائج كما مبينة في جدول (15).

جدول (15) الاختبار التائي لعينتين مستقلتين لإيجاد الفرق بين الجنسين في مستوى الإخفاقات المعرفية.

\begin{tabular}{|c|c|c|c|c|c|c|}
\hline 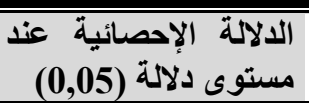 & المحسوبة التائية & الحرية & الانحراف & الحسابط & العدد & الطلسية \\
\hline \multirow{2}{*}{ الفرق دال احصائياً } & \multirow{2}{*}{6,539} & \multirow{2}{*}{498} & 13,19 & 98,15 & 272 & الإناث \\
\hline & & & 21,15 & 87,89 & 228 & الأكور \\
\hline
\end{tabular}

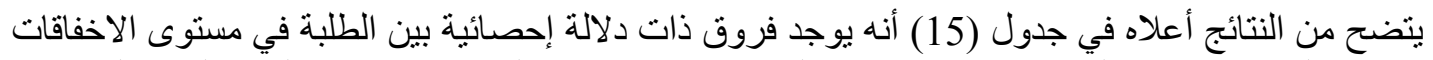

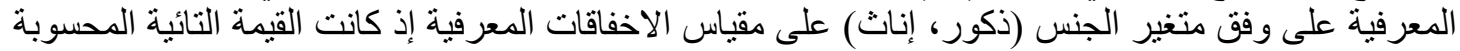
(6,539) اكبر من القيمة التائية الجدولية (1,97) عند مستوى دلالة (0,05) وبدرجة حرية (498)، ولصالح الإناث في مستوى الاخفاقات

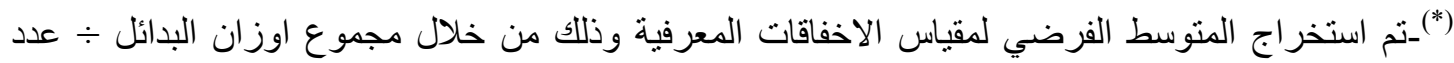
البدائل × عدد الفقر ات البالغة (25) فقرة يصبح الوسط الفئل الفرضي (75). 


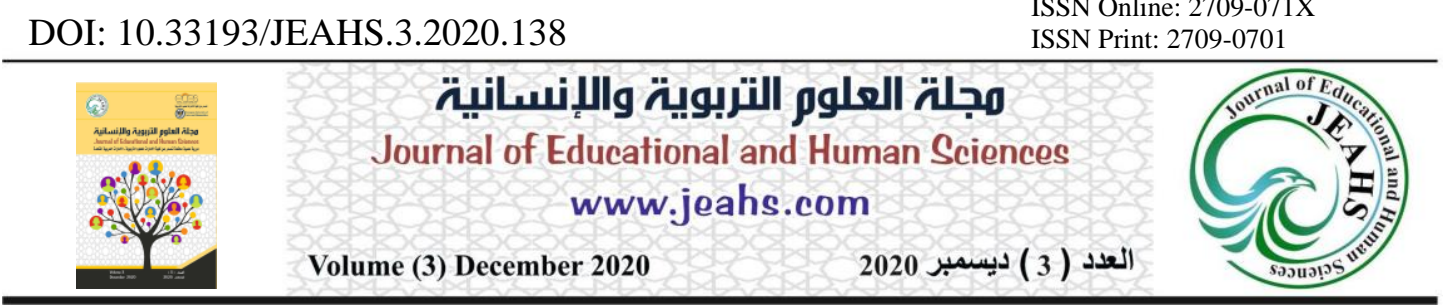

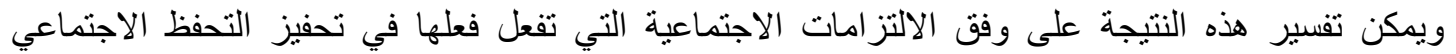

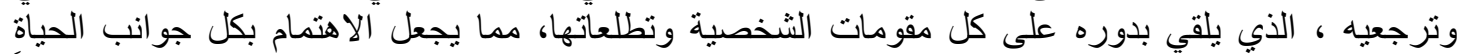

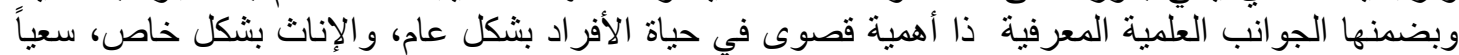

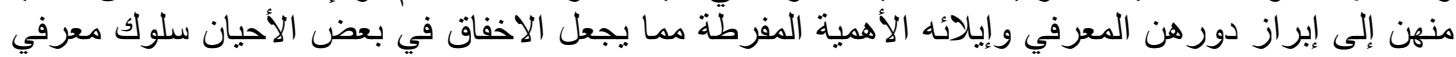

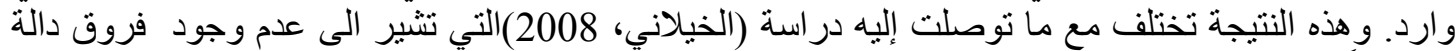
إحصائياً وفق متغير الجنس لدى طلبة الجامعة في الإخفاقات المعرفية.

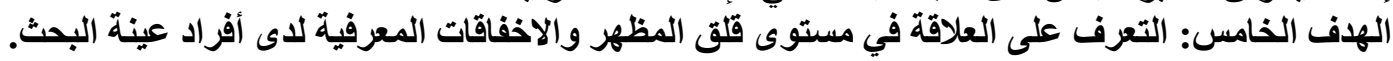

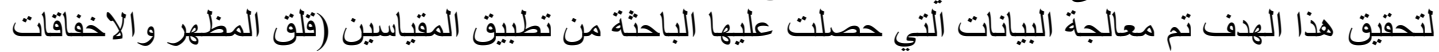

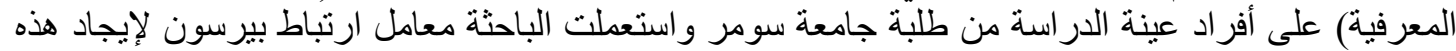

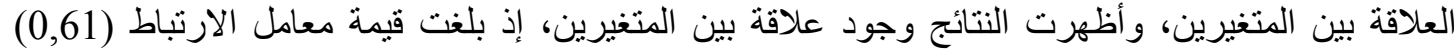

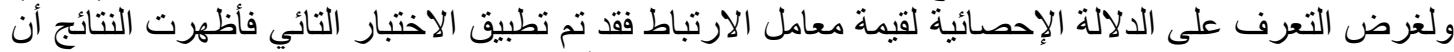

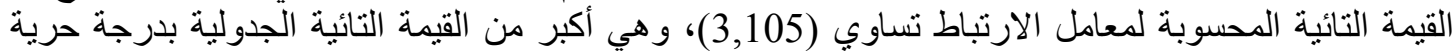

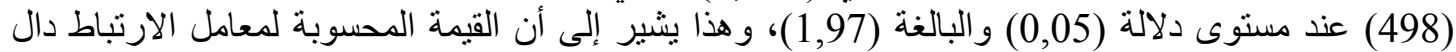
إحصائيا عند مستوى دلالة (0,05) وجدول (0,05) ولبالة (16) يوضح ذللك.

جدول (16) معامل الارتباط بين متغيرين قلق المظهر والاخفاقات المعرفية

\begin{tabular}{|c|c|c|c|c|c|}
\hline \multirow{2}{*}{ 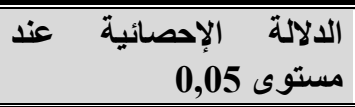 } & \multicolumn{2}{|c|}{ القيمة التائية } & لدرجة & \multirow{2}{*}{ قيمة معامل الارتباط } & \multirow[t]{2}{*}{ أفراد } \\
\hline & الجدولية & المحسوبة & الحرية & & \\
\hline دالة احصائياً & 1,97 & 3,105 & 498 & 0,61 & 500 \\
\hline
\end{tabular}

يتبين من النتائج أعلاه في جدول (16) أن هنالك علاقة بين قلق المظهر والاخفاقات المعرفية ، أي انه كلما

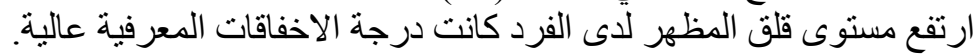

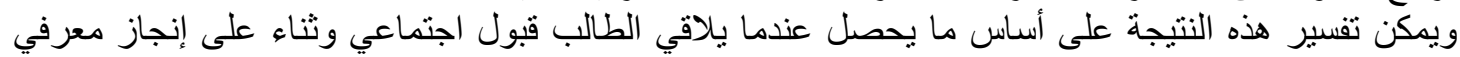

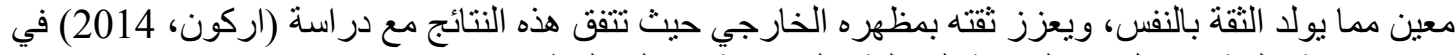
وجود علاقة سلبية بين كل من الدافعية الداخلية و الخارجية مع قلق الثارجية المظهر.

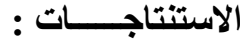

بعد الانتهاء من فرز نتائج البحث الحالي توصلت الباحثة إلى عدة استنتاجات ومنها:

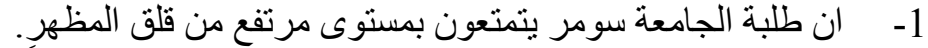

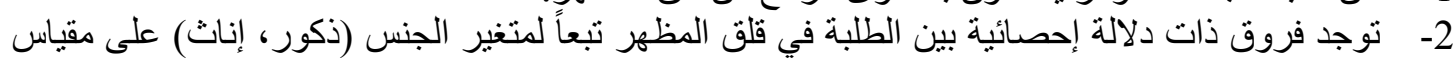

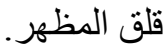

3- ارتفاع مستوى الاخفاقات المعرفية لدى طلبة الجامعة الذين شملتهم الدراسة الحالية

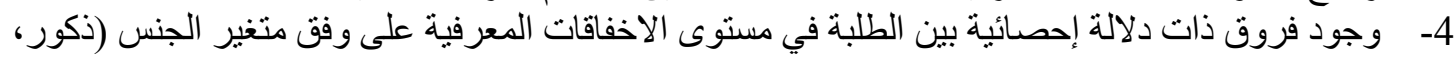

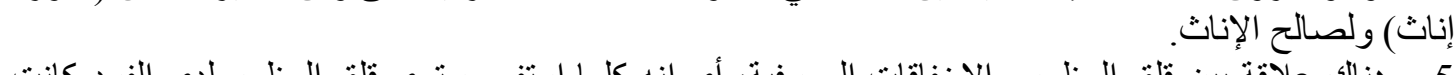
5- هناك علاقة بين قلق الإناث المظهر و الاخفاقات المعرفية، أبي إنه كلما ارتفع مستوى قلق المظهر لدى الفرد كانت درجة الاخفاقات المعرفية عالية.

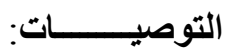

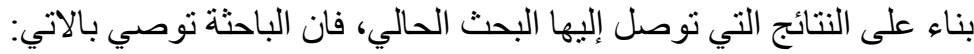

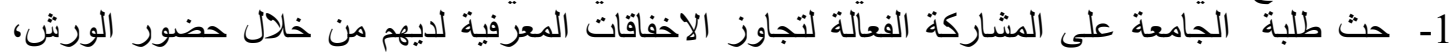

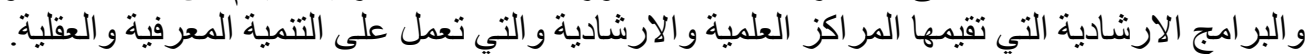

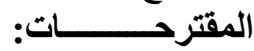
تقترح الباحثة إجر اءات در اسات لاحقة منها ما يلي: 1- إجر اء در اسة تهدف الى قياس قلق المظهر لفئات عمرية مختلفة ومتغير ات كالإسناد الاجتماعي . 


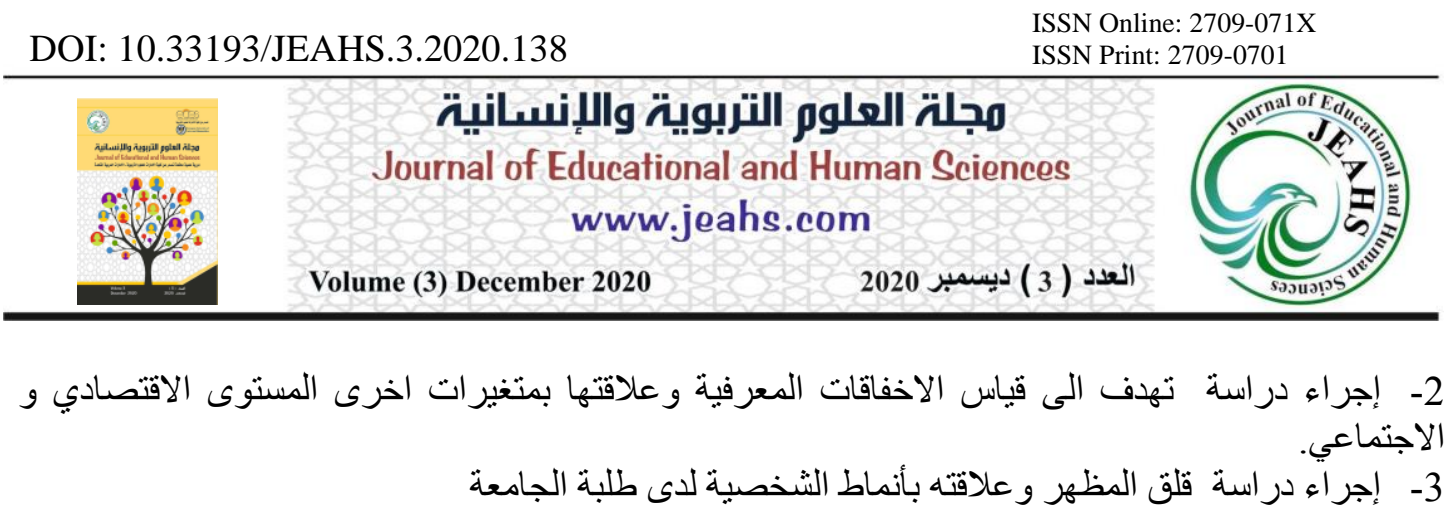

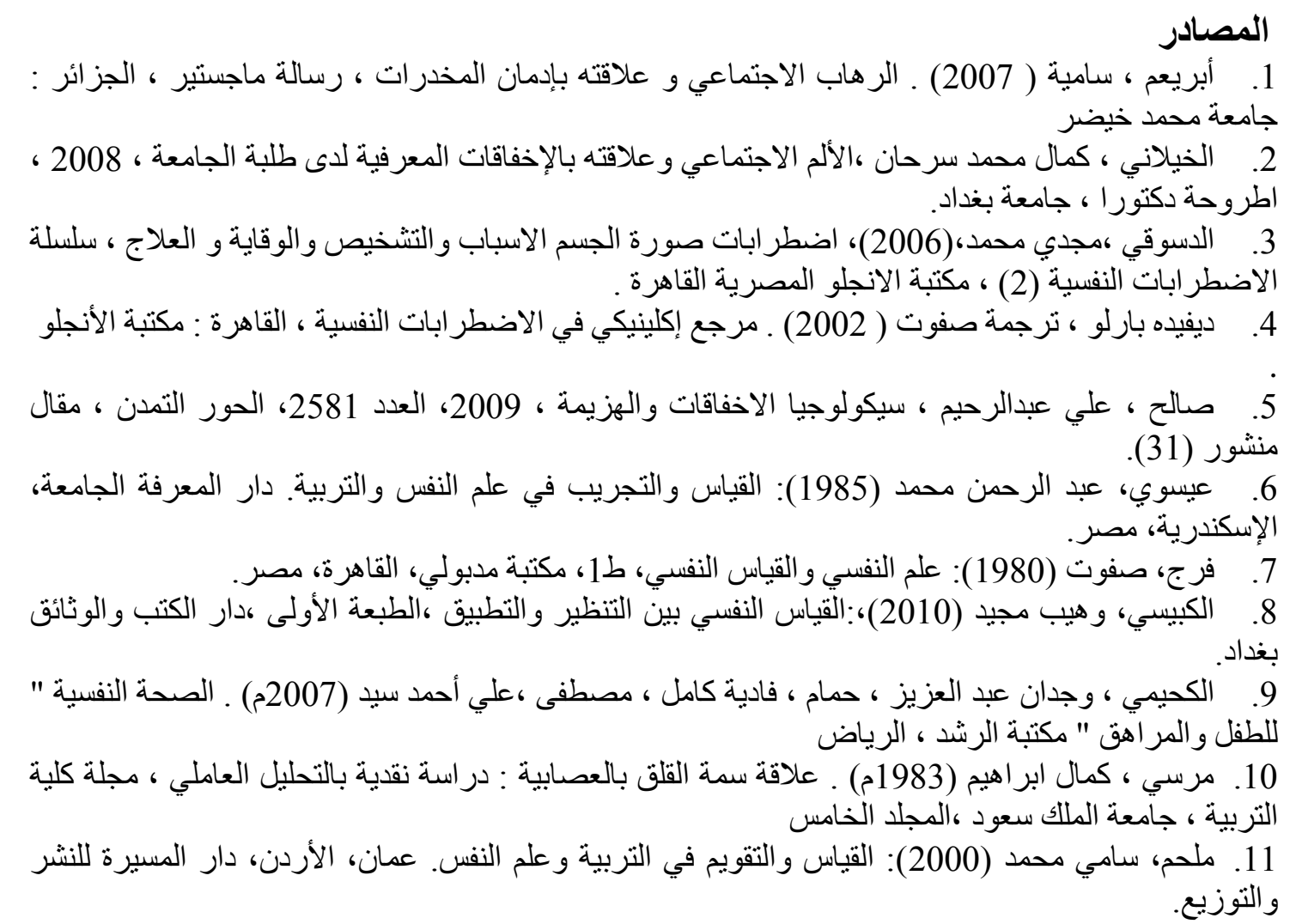

12. Baumeister, Roy F \& Vohs, Kathleen D (2007). Encyclopedia of Social Psychology, Vol 1, USA : Sage Publications

13. Baron, R \& others (1980): psychology understanding Behavior 2ed Halt

14. Broadbent, D.E., Cooper,p.F., Fitz Gerald, p., \& Parkes, K.R. (1982). The Cognitive Failure.

15. Daniel, M \& Jessica, L (2005): Cognitive failure in every life. New York: Guilford press

16. Hart, E . A , Leary, M.R., \& Rejeski ,W.J (1989) : The measurement of social Physique anxiety . Iournal of sport and Exercise Psychology

17. Koskina , \& et . al , (2004) : Social Appearance Anxiety and bulimia nervosa eating and weight disorders . E W D , 16 (2)

18. Krane , V , Stiles - Shipley , J . A , Waldron , J, \& Michalenok , (2001) Relationships amony body satisfaction, social physique anxiety, and eating behaviors in female athletes and exercisers . Journal of sport Behavior.

19. Leary, M.R. \& Atherton,S.C.(1986): Self- efficacy social anxiety and inhibition social en counters Journal of social en clinical psychology (4)

20. Margraf , J. \& Rudolf , B (1999) : Anger in social situation as concept of social 


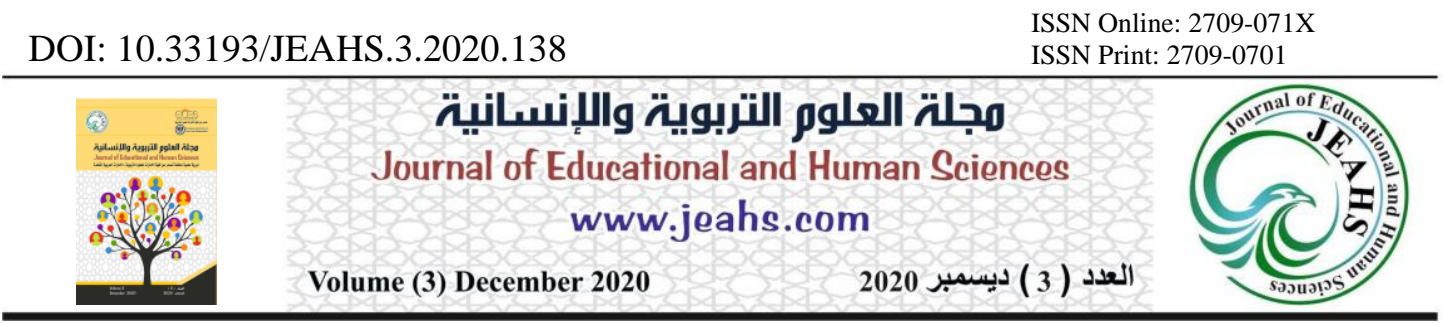

pholpia margrave . J . and Rudolf , K , social competence social phobia Germany Schneider

21. Merckelbach, T. et. al., (1996): Memory and cognitive failure, fisher Books.

22. Nevid, J. S., Rathus, S. A. and Greene, B. 2003. Abnormal psychology in a changing world, Upper Saddle River, NJ: Prentice Hall

23. Pope, H., Phillips, K.A. and Olivardia, R. 2000. The Adonis Complex, Simon and Schuster :NY.

24. Ruffolo, J.S., Phillips, K.A., Menard, W., Fay, C. and Weisberg, R.B. 2006. Comorbidity of body dysmorphic disorder and

25. Smith . \& et . al (1983) : The Behavior angen and Neuvoticism British, Journal of Clinical Psychology . 23 .

26. Stacy, A. 2000. Amount of Influence Selected groups Have on The Perceived Body Image of fifth grads, Master's Thesis, The Graduate College, University of Wisconsin- Stout, Menomonie.

27. Strenberg, C.(1999): Play Therapy with children Osney Mead Oxford-

28. William .G.W. Dardain Apparal Theories and Other Other Theorists , 2000 